Article

\title{
Navigating Contested Winds: Development Visions and Anti-Politics of Wind Energy in Northern Kenya
}

\author{
Gargule A. Achiba \\ Centre for Development and Environment, University of Bern, Mittelstrasse 43, CH-3012 Bern, Switzerland; \\ gargule.achiba@cde.unibe.ch
}

Received: 13 November 2018; Accepted: 29 December 2018; Published: 4 January 2019

\begin{abstract}
State-led development visions and the accompanying large-scale investments at the geographical margins of Kenya rest on the potential of public-private partnerships to fast-tract sustainable development through accelerated investments. Yet, the conceptualisation, planning and implementation of these visions often deploy a depoliticising development discourse that reinforces and expands long-standing misconceptions about the margins primarily directed at pastoral livelihoods and related communal land tenure. This paper illustrates how the implementation of a wind energy project employs the corporate strategies of depoliticising both land claims and development interventions. In Northern Kenya, private sector participation in large-scale wind energy infrastructure has created a complex development apparatus in which players are empowered to undertake the accelerated investments required to shape the delivery of the Kenya Vision 2030 in the region. An analysis of corporate actors' strategies in the implementation of the contested wind farm presents a depoliticised framing of "low-cost green energy", representations of pastoral land tenure and corporate social responsibility strategies through which dispossession is justified and legitimised. This case underscores the extent to which corporate counterresistance is shaped by the reproduction of a historical depoliticised discourse about pastoralism and communal tenure and challenges the traditional narrative of government hegemony against local resistance to large-scale land acquisitions (LSLAs).
\end{abstract}

Keywords: large-scale land acquisitions; common pool resources; green energy; corporate social responsibility

\section{Introduction}

Recent scholarship has produced a wide range of insightful analyses on the trajectories and dynamics of large-scale land acquisitions (LSLAs) and related grassroots mobilisation against their dispossessing potential. Within this vast literature, LSLAs of common property resources (CPRs) have received limited attention despite their legal vulnerability and preferential targeting by the grabbing processes. Nevertheless, several important studies have highlighted the historical shifts in the commodification of land relations [1], the role of law and government policy embedded in neoliberal economic ideologies in consolidating dispossessory trends in CPRs [2] and the political reactions from below to commons grabbing [3]. This paper contributes to these debates by emphasizing the role of historical construction and denial of the proprietary character of communal tenure and their reproduction in contemporary technical "development" discourse [4] in creating and perpetuating commons dispossession. Contemporary LSLAs, which are deeply embedded in institutions and policy planning systems of the state, are presented as "new" development visions to throw off aid dependencies [5] and are expressed as an "unavoidable prerequisite for implementing the productivity-enhancing technologies" [6], hence dispossessing indigenous communities by securing exclusionary rights over their common pool resources. 
Drawing from the case study of a wind power development project in Northern Kenya, the Lake Turkana Wind Power Project (LTWP), this contribution critically analyses the historical and contemporary technical discourse around the "visions of viability" [7] of pastoralism enacted through colonial and postcolonial policy and planning and their practical and political consequences for LSLA of community land. The key questions guiding the analysis of this contribution are as follows: how does state 'development' discourse on pastoral commons inform present-day legitimisation of commons dispossession, and, more importantly, how do commercial and political interests select from diverse delegitimising discourse to maintain and promote alternative investments in communally owned land? To answer these questions, this paper analyses how the introduction of investment designed to provide reliable and low-cost green energy to the pastoral commons at the margins of Kenya reproduces colonial misconceptions on local livelihoods, customary tenure and the utilisation of common pool resources. The pursuit of the LTWP project, a new flagship project under the Kenya Vision 2030, has created unresolved contest between corporate entities involved in the LTWP project and indigenous pastoral communities trying to resist exclusion from their access to critical CPRs.

The case study in this paper is derived from Sarima in the Mt. Kulal region of Marsabit County, an arid region in Northern Kenya and home to autonomous and tribally-based migratory pastoralist societies that include the Rendille, Samburu, Gabra and Turkana. With its large central plains, the Mt. Kulal region covers approximately $20,000 \mathrm{~km}^{2}$ of bushland and dwarf shrublands dotted with lines of seasonal sand rivers that dry out in the open plains. Despite the low annual rainfall of less than $500 \mathrm{~mm}$, the proximity of the Eastern shores of Lake Turkana has important impacts on the hydrology of the area, including being an important source of perennial grasses. As a major dry season resource with enough open grasslands, the Mt. Kulal region is a point of convergence for migratory pastoral groups, which necessitates intertribal negotiations for rangeland pasture and water resources. In 2006, the isolated and hitherto marginalised Mt. Kulal region was set for transformation with the authorisation of an LTWP comprising a wind farm with 365 wind turbines and related infrastructure on 150,000 acres of land, a high voltage substation, an associated transmission line and $204 \mathrm{~km}$ of road upgrades. In 2014, communities in the Laisamis Constituency brought a case to Kenya's Environment and Land Court (ELC) for the immediate cessation of all project activities by the LTWP, citing irregular, unprocedural and illegal acquisition and annexation of community land, commissioning of a "self-serving" [8] Socio-Economic and Environmental Impact Assessment (SEIA) by the proprietors of the LTWP project and denial of the indigenous status of communities around the Mt. Kulal region. Challenging the community case in the ELC, the LTWP, through its lawyers, submitted that the land in question was "uninhabited-the community was not being merely left on the roadside" and "situated in the middle of nowhere" and that LTWP investment was "a Kenya Vision 2030 flagship project which has benefitted the community immensely and will continue to benefit them." [8].

The countercontestation to the community opposition to the LTWP offers a glimpse into the development discourse that legitimises commons grabbing. The LTWP fits a wider and well documented pattern of the depoliticisation of development [4] and the extension of state control through a specific knowledge structure that presents pastoralism as unviable and legitimises large-scale investments as the ideal. Furthermore, it demonstrates how, as argued by Cousins and Scoones [7], by creating technical discourse around visions of economic viability, large-scale investments become enacted through policy and planning without interrogation. Further, the LTWP case illustrates the relevance of the notion of the "anti-politics machine" as a lens to analyze depoliticisation within development discourse. The discussion presented in this paper about the depoliticisation of development interventions is based on the understanding of pastoralism as a rational adaptation to an environment dominated by variability through mobility and utilisation of common pool resources (CPR) held in common property institutions. Though mobility, pastoralists can interface extreme variability in the environment with variability in the production system [9], hence exploiting the economic benefits associated with flexibility [10]. 
This paper draws on James Ferguson's thesis of an anti-politics machine to examine historically conditioned colonial discourses about pastoralism and the tradition of their reproduction in development discourses in postcolonial investment and policy in pastoral regions to legitimise the dispossession of commons. The paper proceeds as follows: The next section presents Ferguson's anti-politics machine framework before a presentation of historical representations and dispossession of the pastoral commons in the Kenyan context. This is followed by descriptions of the study area and research methods. The paper then considers the key anti-politics machine derived from the LTWP's wind power development to identify a myriad of strategies employed by the LTWP project to justify its investment. These strategies are then used to demonstrate the discursive relations between the LTWP's anti-politics machine and the broader historical and contemporary development discourse that shapes the dispossession of pastoral commons. Finally, we conclude with a discussion on the relevance of depoliticisation on commons dispossession and how such contested appropriation of commons constitutes "resilience grabbing", with deleterious impacts on commons reliance on CPRs.

\section{Anti-Politics Machine and Common Pool Resources in Kenya}

A theoretical understanding of anti-politics in development discourse and practice was developed by anthropologist James Ferguson. While studying state power and development discourse in Lesotho, Ferguson illustrated how supposedly "politically neutral" development interventions overlooked complex political and structural realities within specific communities-what he termed "anti-politics machines" of development [4]. The anti-politics machine thesis argues that development institutions have a tendency to "generate their own form of discourse" by creating "a structure of knowledge" around subjects of development interventions that have the effect of expanding and entrenching the bureaucratic power of the state as well as projecting a representation of economic and social life that denies and suspends politics and its effects [4]. Consequently, development interventions "inevitably adopt a technocratic and universalizing approach that tends to obscure both the essentially political character of many development problems and the local and national political processes on who gets to define and benefit from development' [11]." Ferguson further observes that despite the widespread and apparently unintended consequences of their development interventions, governments and their networks of donor agencies continue to justify increased and similar interventions based on the same erroneous assumptions. However, as Buscher argues, "anti-politics can serve the necessary political strategy to try to 'make things happen in' or 'get things out of' intensely politicised and increasingly commoditised environments [12]."

Ferguson's work has been criticised for ignoring a "third discourse" in development that represents the subject of development projects as "the rurally based, land-poor migrant worker" who would benefit from having a "market, or a road, or a school, or a clinic only 5-10 miles away, instead of 50 [13]." Similarly, Ferguson's argument that the development apparatus constitutes an "anti-politics machine depoliticising everything it touches" [4] has been questioned. Examining historical and contemporary development interventions in Indonesia, Li argues that development programs may "become a politically charged arena" in which rules and claims are constantly reassessed and reworked [14]. However, Ferguson's thesis has been extensively used to critically examine how knowledge is generated and used in development and has continued to be provide useful analyses of the effects of development interventions. This paper employs Ferguson's framework to structure an analysis of legitimising discourse related to historical and contemporary dispossessions of commons in development interventions in Kenya. The framework's focus on construction of development representation and their institutional rationales is appropriate given the development policies and strategies employed in the study area. The four theoretical premises for development representation and the institutional rationales of Ferguson's framework included the following [4]:

(a) That the target of development programs is not yet incorporated into the modern world and that investments in infrastructure, education, introduction of cash economy, etc., can "open it up" and transform it into a developed modern economy; 
(b) That the target of development programs "must be agricultural" so that its development can be achieved through technical inputs and extension services;

(c) That the target of development programs constitutes a national economy and thus supports the idea of national economic planning and the notion and idea of sector-based programs; and

(d) That the target of development programs is subject to the idea of governmentality-the control of a neutral, unitary and effective national government-and is thus responsive to planners' blueprints.

\section{The Historical Processes of Commons Representations in Kenya}

In Kenya's arid and semiarid lands (ASALs), depoliticisation has long been associated with the social relations related to land and productivity of the dominant land uses. The coming of colonial rule initiated two changes that shaped the future of government policy in relation to ASALs. First, Kenya's ASALs have a problematic history whereby the colonial administration not only constructed the dominant land use-pastoralism —as an "irrational" way of life but instituted legal and policy strategies to introduce private property rights in the ASALs, thereby curtailing mobility and taking away common property resources from the control of flexible customary resource management institutions. This representation of pastoralism was not only isolationist and discriminative but also laid down policies for its restriction, as observed by Zwanenberg:

"The colonial view had consistently been that pastoral, and particular nomadic activities, were primitive, backward and to be discouraged. This view underlay the permanency of the stock control regulations, and especially the quarantine [screening] regulations, which precluded any official encouragement of stock trade." [15]

Pastoral livelihoods in the ASALs depended on spatial and social mobility to interface extreme variability in the environment with variability in the production system [9] by making use of a wide range of natural resources, social resources and opportunities [16]. However, colonialism created boundaries challenging pastoralists' imperative of free movement, "disrupting the natural process of adjustment that maintained a balance between people, land and livestock [17]." This colonial restructuring reduced the mobility on which pastoralism depended. In addition, increasing droughts and intensification of disease outbreaks pressured pastoral households.

Second, the colonial white settlers erroneously perceived any unoccupied piece of land as "no man's land" and annexed it. Under the colonial "civilisation" mission, the colonial administrators began the process of individualisation of rights in land as "the first stage in the modern departure from the customary system of landholding [18]." This ideology enabled European settlers and corporations to take for themselves the best land and mineral resources, including fragmenting the pastoralist domain and fracturing pastoralist communities, which, according to Markakis, is "a historic injustice that awaits redress [19]." The colonial state not only enforced individual rights in land to exclude others but also "claimed all apparently 'vacant' or 'unused' land for itself as 'public land', so that occupiers lacking express approval could be treated as squatters in the land of their birth, and evicted [18]." By imposing private property rights on critical rangeland resources, such as dry season grazing areas and migration routes, the colonial government contributed to the transformation of pastoral rangelands, supporting and reproducing vulnerability to risks.

The independent Kenyan administration, in a bid to achieve development and defeat the three ills of disease, ignorance and poverty, stated that development planning is the most important instrument to achieve those goals. However, the colonial regulatory and policy infrastructure was transferred largely intact and was endorsed and funded by international development agencies. In the ASALs, narratives of scarcity in lowland ecologies and productivity of pastoral economies became the cornerstone of development planning. Most of the development strategies adopted after independence were "technical" solutions that had "the allure and unquestionable legitimacy of science [16]." For instance, the premise of range management concepts such as "carrying capacity", 
"cattle complex" [20] and "tragedy of commons" [21] became a handy simplification of the complex African pastoral system. Accordingly, issues of donor mobilisation around critical areas of ASAL development became a key part of government interventions to include volume and value production. The 1970s saw the introduction of group ranches that were "promoted with the intention of easing the transition from communal tenure and encouraging commercial production by offering veterinary support and better access to markets [16]." However, the group ranches model was incompatible with the way in which pastoralists managed collective access to resources [16], and consequently, critical common property resources were lost, leading to the displacement of pastoralists

Recent trends in regional and national development policies towards the ASALs have seen efforts to "rectify" [22] this historical marginalisation through inclusive policies and state-led development "visions" that aim to open up these areas as "new frontiers for development" and incorporate them into the state [5]. These "new visions" of development are being created to increase agricultural productivity [23], generate mineral resources for export [24] and expand infrastructure required for regional economic integration [25]. These new visions were also responsible for a change in narratives from constructing pastoralism as an "irrational way of life" to understanding the unique challenges to the development of the region and the rationale for protecting and promoting mobility and supporting the pastoral customary institutions [26]. The deployment of LSLAs and the related infrastructure installations have been accompanied by many perceived advantages, including addressing unsustainable fossil-fueled economies and the Earth's climate crisis [27,28]. Consequently, there is considerable pressure to invest in reenabled energy projects globally as part of a long term strategy to achieve the dual goal of meeting targets to increase shares of renewable energy (and by extension reduce the reliance on greenhouse gas (GHG)-emitting fossil fuels) and enhance environmental sustainability $[29,30]$. However, renewable energy projects around the globe have been associated with "land grabbing", which is "a measure used by some governments (and corporations) to meet their food and energy requirements by acquiring land in a foreign country [31]." Experiences around the world indicate fierce sociopolitical conflicts in relation to renewable energy installations [32,33]. Traditionally, the terrain of contestation comprises diverse issues ranging from "struggles against dispossession" involving expulsion and dispossession of land from local communities to issues of incorporation and the terms of such inclusions [33,34]. As a result, contestations against mobilisation around renewable energy have not only mobilised a wide range of actors, including human rights, agrarian and environmental activists [34] but also involve diverse strategies of resistance from covert to more open opposition to dispossession and terms of inclusion $[35,36]$.

LSLAs involve a great deal of political dynamics involving transformations in existing infrastructure, land rushes and reconfigurations of local livelihoods [37,38]. In the context of common property systems, land rush has been associated with the unintended effects of transforming and redefining common land rights essential for the communal systems of production that ensure the sustainable use of natural resources. Among the African commons, this is particularly exacerbated by the weak status of community-derived ownership over the commons [39] from years of government policy measures that sought to take rights and responsibilities related to natural resources out of the hands of local communities [39,40]. While government policies and their impacts on communal ownership do play a significant role in the ease by which commons are easy targets of LSLAs in general, the vulnerability of commons to LSLAs has been thought to be exacerbated by the incompatibilities between uses, claims and values that common users attach to natural resources on one hand and the commodification goals of governments that seek to formalise property rights on the other $[2,41,42]$. As LSLAs unfold, the dispossession of commons is leading to a loss of principal and scarce natural capital, with grave implications for social and political stability.

In Kenya, the development vision of achieving prosperity and middle-income status by 2030 contained in Kenya Vision 2030 has impacted the scale and approaches to commons dispossession. Growing recognition of ASALs as "new frontiers of opportunity" were accentuated in the government's 
U-turn in its understanding and investments in the ASALs after decades of marginalisation, and this has been articulated in development visions such as Kenya Vision 2030 with massive investments in infrastructure, energy and irrigated agriculture. Vision 2030 and related policy visions have an array of strategies for transforming the ASALs. First, through the creation of new development corridors-"networks of roads, railways, pipelines and ports that facilitate the movement of commodities" [43] — the frontier areas are expected to be incorporated fully into the state [5]. Second, these strategies aim to "create an enabling environment for private sector participation in infrastructure and technology development, including appropriate tax breaks and incentives, in all areas of infrastructure investment [26]." Third, Vision 2030 aims to transform the country into "a newly industrializing, middle income country providing a high quality of life to all its citizens in a clean and secure environment", including sector specific flagship projects. While these visions are conceptualised as transformations to space, there is a great deal of uncertainty on exactly when and where they will materialize [5]. In addition, it is unclear whether the redesignation of ASALs as new frontiers of opportunity is demonstrative of the recurrent reassessment of development concepts witnessed in the last five decades or is, in fact, a reinterpretation of the quality of territory for green and bioeconomic forms of development [44].

The legacy of these development visions on ASALs is already evident in the inevitable physical and social fragmentations of the ASALs' landscapes, claims of dispossession of indigenous communities and contested land politics. According to Browne, one of the major Kenya Vision 2030 flagship projects, the Lamu-South Sudan-Ethiopia Transport (LAPSSET), "has failed to realise the developmentalist "Africa rising' narrative of its promoters" [45]. For pastoral commons along the path of the LAPSSET project, inevitable disruptions of migration routes and losses of crucial dry season fallback zones during drought [46] constitute what has been dubbed "resilience grabbing". Moreover, development visions have been associated with "the new scramble for Africa": dispossession of land characterised by "the haste, the lack of negotiation about conditions, the privileging of foreigners over locals and when we know that c. $70 \%$ of the land thus far acquired is not (yet) taken into production [47]." Furthermore, the framing of development visions often engenders a discourse of depoliticisation of the local land use and the natural resource context typically enacted by governments and their investors to legitimise dispossession as state appropriation of "unused" or "vacant" land [47]. This sees the state exhibiting anti-politic strategies not only through "development by dispossession" but also through encouraging and endorsing corporate agencies' CSR and greenwashing strategies of sustainable development narratives to preempt resistance and minimise conflict.

\section{Methods and Study Site}

\subsection{Data and Methods}

The empirical material for this article is drawn from field work that took place between July 2016 and June 2018 in the Northern Kenya County of Marsabit (see Figure 1), where, since 2006, the local government authorities with support from national government institutions has proactively enabled a private corporation to acquire 150,000 acres of community land to implement a wind power project expected to add $310 \mathrm{MW}$ to the national grid. The objective of the field work was to examine mechanics of the 2006 acquisition of 150,000 acres of community land for wind power development by the LTWP consortium, grassroots political resistance to the project and attempts by state and corporate actors to restrict and manage contestation of the wind power project. This paper employed a qualitative data collection strategy aimed at identifying: (a) the main actors in the grassroots resistance to the LTWP project, their characteristics and their underlying ideological and campaign strategies and the subjects of their suit; (b) the coercive and anti-political maneuvering and counterresistance measures of the LTWP project and affiliated government institutions; and, (c) how diverse delegitimising "development" discourse employed by the LTWP project is associated with historical delegitimisation of pastoral commons and the generalizability of these strategies in similar contexts. This strategy 
entailed the collection of the three types of data used in the study: semi-structured interview responses, a content analysis of ELC proceedings and archival and secondary data from government policy and publicly available LTWP project documents.

First, the main actors in the grassroots resistance to the wind power project were identified through a review of court documents relating to the ELC Civil Suit No 163 of 2014 and key informants. At this stage, two main groups of actors were identified: (a) the petitioners (TPs) and (b) the interested parties (IPs). Further, apart from the LTWP project, which the TPs identified as the main respondent, a third category of actors was identified: (c) government institutions with direct responsibility for land administration in the study area including the County Government of Marsabit, The Attorney General, the Chief Land Registrar and the National Land Commission (NLC). Semi-structured interviews were administered to the members and the leadership of two grassroots groups in the ELC Civil Suit No 163 of 2014, which included a set of key informant surveys (i.e., three key leaders in each group; $\mathrm{N}=6)$; a set of key informants in the areas represented by each group $(\mathrm{N}=16)$; key informants drawn from the National Land Commission (NLC) $(\mathrm{N}=2)$; officials of the County Government of Marsabit $(\mathrm{N}=5)$; members of County Representatives in the Marsabit County Assembly (CA) $(\mathrm{N}=6)$; and political aspirants for national and county assembly seats in Laisamis Constituency $(\mathrm{N}=5)$. Responses from the TPs and IPs revealed the historical context and the channels of expression of the grassroots resistance to the LTWP project, the coercive and anti-political maneuvering and counterresistance measures of the LTWP project and affiliated government institutions. Details of community land acquisition for the project were obtained from records of the now defunct Marsabit County Council and semistructured interviews with four former Marsabit County Council councilors and five serving County Representatives in the Marsabit County Assembly (CA). Government policy documents, LTWP documents, correspondences and court proceedings were obtained to triangulate community claims and the corporate counterclaims and narratives legitimising the project. Archival research conducted in the Kenya National Archives between July 2016 and June 2017 was used to understand historical aspects of communal land and ASALs legal land institutions.

Second, the anti-political nature of discourse associated with the LTWP project case was investigated by reviewing publicly available government and company documents and the proceedings of the ELC Civil Suit No 163 of 2014. Through critical analysis of documents, court proceeding and related rulings and additional materials from secondary sources, the paper identified discourses associated with Kenya's key development visions and green energy, including counter-framings of the TP application; the company's representations of community land and related claims of illegal land acquisition; and the meanings associated with the company's corporate social responsibility (CSR) investments and the indigenous status of the local communities. These analyses paid attention to the practices and strategies of the LTWP project regarding the "depoliticisation" of green energy, land redistribution claims of TPs, communal tenure and local communities. Finally, from the analysis of the first two sets of data, the paper identified strategies of depoliticisation, their articulation and the mechanisms for their reproduction employed by the LTWP project and its network of local and national actors as well as how they relate to the dominant colonial and postcolonial discourse that delegitimised pastoral commons and legitimised alternative large-scale investments as the ideal.

However, there is need to highlight a methodological shortcoming of research on "land grab". Given some of the characteristics of LSLAs, Oya points out that land deals generally provide "killer facts that raise awareness and induce action [48]." While certainly not ruling out all sources of potential bias from the interview conducted with key informants-given land (and by extension the LTWP project) is a key issue around which local politics are organised - this paper tries to address these problems by focusing on the multiple layers and contradictions by disaggregating, clarifying and testing various claims and counter claims used by different interviewees, as suggested by Oya. In addition, the paper tries to enhance the comparability of the arguments and counterarguments in the ELC Civil Suit No 163 of 2014 with historical discourse on pastoralism development. 


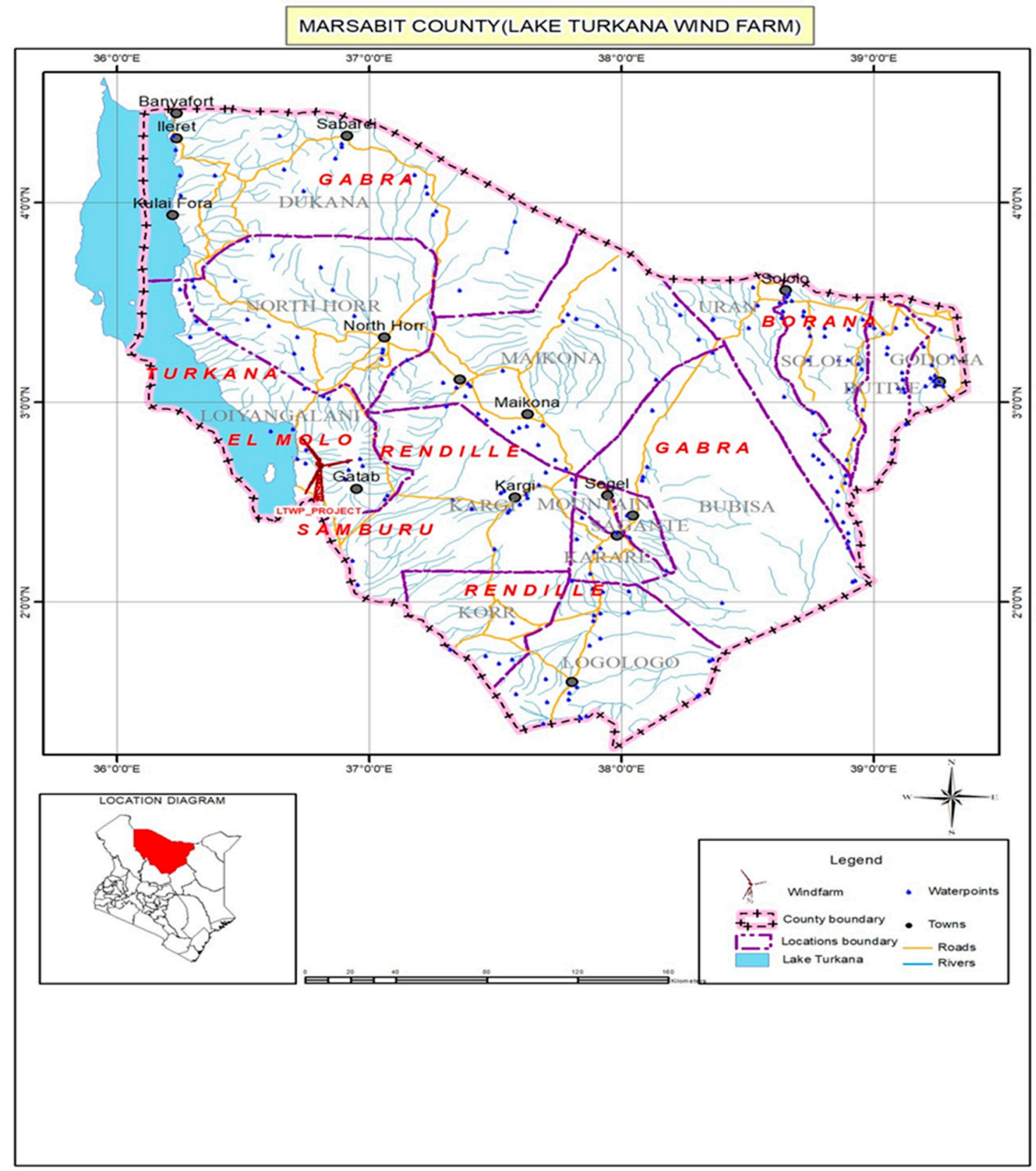

Figure 1. Map of Marsabit County highlighting the study area.

\subsection{Study Area}

Marsabit County falls within the larger ASALs of Kenya and is among the 3 counties comprising the upper Eastern bloc. Marsabit County is the largest county in Kenya in terms of land mass $\left(70,961.2 \mathrm{~km}^{2}\right)$ and has a population of 291,166 [49] people, which includes three major migrant pastoralist groups: Boran, Gabra and Rendille. Marsabit County comprises extensive plains lying between 300 and $900 \mathrm{~m}$ above sea level and an extensive dwarf-shrub grassland or a very dry form of bushed grassland [50]. The county is also endowed with mountain ranges, including the Ol Donyo Ranges (2066 m above sea level) in the southwest, Mt. Marsabit (1865 m above sea level) in the central part of the county, the Hurri Hills (1685 m above sea level) in the Northeastern part of the county and Mt. Kulal (2235 $\mathrm{m}$ above sea level) in the northwest [50]. The constitutive plains comprise diverse ecological zones ranging from subhumid to arid that form a natural habitat for diverse grasses and 
shrubs that provide pasture in different seasons. Migrant pastoral communities utilise these diverse pasture types through the migration of herds.

Marsabit County and the entire arid region of Northern Kenya have been politically and economically removed from the power of the state. According to Catley et al., these borderlands have been "beyond the reach of the state and so the development industry" and, as such, have been designated as "sites of famine, destitution and impoverishment.... while contributing little tax or tribute to state coffers [51]." However, in an apparent U-turn from the marginalisation policy, the Kenyan state embarked on a "rebalancing of national development" through "accelerated investment in previously neglected regions essential for sharing in the promise and benefits of Vision 2030" [26] including "interventions required to bring the ASALs to the same threshold as the rest of the country [52]." The state-led development visions still have the old stereotypes, including a distinct security dimension, but they also articulate a "new departure....to transform them [5]." The premise underlying these development visions is that "the Government will release the latent potential of the arid and semiarid lands in livestock, tourism, and renewable energy, and regions comparative advantage in its strategic location as Kenya's bridgehead to the markets of North Africa and the Middle East [26]." Some of the major projects outlined in Kenya's development vision for the development of Northern Kenya include large-scale infrastructure development and renewable energy development, including "prioritizing the development of transport corridors linking Kenya to key markets in Ethiopia, South Sudan and Somalia and beyond them to the Middle East, such as the Lamu Port-South Sudan-Ethiopia transport corridor [26]." Constructed under the "imagery of a seamless Africa" [43] for ease of movement of capital, commodities and people, they have had negative impacts such as the emergence of "economies of anticipation" for benefits and compensations [5].

The LTWP was launched in Sarima in 2006 as a Vision 2030 flagship project with funding from a consortium of international investors. The project website offers a brief introduction to the $310 \mathrm{MW}$ wind farm underlining green energy and partnership with local public power company:

“Once operational, the wind farm will provide $310 \mathrm{MW}$ of reliable, low-cost energy to Kenya's national grid (i.e., approx. $17 \%$ of the country's installed capacity), which will be bought at a fixed price by Kenya Power and Lighting Company Ltd. (KPLC) over a 20-year period in accordance with the Power Purchase Agreement." [53]

The Sarima area of the Mt. Kulal region comprises large arid plains with a hill mass, Mt. Kulal, to the east and Lake Turkana to the west. Endowed with a unique geographical condition, Sarima experiences strong predictable wind streams as a result of fluctuations in daily temperatures between Lake Turkana and the desert hinterland. Located between Mt. Kulal and Mt. Nyiro, Sarima is a valley that acts as a funnel in which wind streams are accelerated to high speeds, $11 \mathrm{~m}$ per second, which are among the highest recorded in the world. Sarima is thus endowed with extractable wind power, which the LTWP has translated into a capacity of $300 \mathrm{MW}$. Consequently, the LTWP was designated as a flagship project of Kenya Vision 2030 to the extent that the project will generate reliable green energy at a lower cost through a public-private partnership (PPP). Following a memorandum of understanding signed between the KPLC and the LTWP on 10 April 2008, the wind farm facility, comprising 365 turbines, a high voltage substation and a transmission line, was begun in 2014. The LTWP, Kenya's biggest PPP, with an investment of over $\$ 700$ million that is expected to increase the country's energy output by $15-20 \%$, was promoted as socially and environmentally benign with positive impacts on sustainable energy, job creation and the development of rural Northern Kenya.

Designated as the largest wind farm in Africa, the LTWP project also drew the interest of international development funding agencies with interest in renewable energy and carbon credit generating assets. The project is financed by a consortium of international donors, including the African Development Bank (AfDB), Finn Fund, Norfund, the Danish Investment Fund for Developing Countries (IFU), the Danish Export Credit Agency (EKF) and Vestas, which manufactures turbines. Initially, the World Bank was interested in providing risk guarantee for the project but withdrew its support in 2012 with concerns around Kenya's capacity to consume all of the electricity generated 
by the project [54] and fears that the Power Purchase Agreement would expose the country to large financial risk [55]. However, in 2018, the International Finance Corporation (IFC), World Bank's corporate finance branch signed a cooperation agreement with the Finnish government for a $€ 114$ million loan to the LTWP project as part of its support for wind power projects across the continent [56]. After the withdrawal of the World Bank, AfDB stepped in to provide partial risk guarantee to the other project financiers.

Relatedly, it was not long before the procedure of land acquisition and the socio-economic and environmental impacts of the project were questioned considering the socioecological and cultural and religious affiliations attached to the region by the pastoralist communities. In 2014, residents of the Laisamis Constituency and Karare Ward in Marsabit County filed a lawsuit in Kenya's ELC to contest the "unprocedural and illegal" acquisition of 150,000 acres of community land in Sarima, including a lack of public consultation or compensation for affected communities. The land in question was constitutionally designated as Trust Land with clear procedures for setting apart public consultation and compensation in accordance with the Trust Lands Act Cap 288. The communities argued that the unprocedural acquisition of their land will not only alter the use of land but will also permanently alter the landscape, which will render them unable to seasonally and cyclically use pasture lands, cultural sites and a camel migration corridor to Lake Turkana.

Furthermore, the petitioners, acting on behalf of pastoral communities that jointly utilise the common grazing plains of Sarima, accused the LTWP of carrying out a "self-serving Environmental and Social Impact Assessment (ESIA)" [57] without involving the communities in the area and without evaluating the possible negative impacts of the project on the economic, social, cultural and physical well-beings of the indigenous communities in the area [8]. Moreover, the petitioners claimed that the application for an additional 110,000 acres in addition to the LTWP's initial application of 40,000 acres occurred at an excessively rapid pace and with substantial secrecy, thereby disallowing time for procedures for setting apart community land in accordance with the Trust Lands Act. According to the petitioners, the unprocedural acquisition of community land and the possible negative impacts of the project on local communities have led to growing public discontent and hence their application to the ELC for termination of the wind power development.

Nevertheless, the construction of the wind farm continued without interruption, even as the ELC determined that the issues before it were important legally. In a court ruling dated 18 March 2016, the ELC ordered the LTWP to confine its activities to the 87.5 acres it was given to utilise and to ensure that resident communities' access to Lake Turkana through the project was not blocked [8]. In addition, the case was referred for mediation by the Marsabit CA to encourage an out of court settlement of the issues in dispute. Despite delays in the determination of the court, there was little concerted resistance to the project except in the Kargi location, where the company trucks were blocked by the Kargi residents from accessing the wind site through the Marsabit-Kargi-Loiyangalani route. Other road blockages by the local communities were reported from settlements along the Laisamis-Loiyangalani route with communities reporting concerns around employment and frustrations over delays by the LTWP project to address their complaints [58]. The lack of concerted community activism was attributed to the fact that, despite widespread opposition to the project by communities and their local leaders, some local political leaders from the area and the local government were in full support of the project, to which a Rendille elder desperately remarked, "with some of our leaders eating from the enemy's (LTWP) pot, how can we achieve a united front to confront this monster?"(Interview_024_Rendille Elder, interviewed in Meru Law Courts on 17 March 2016). Indeed, this not only created tension between the two groups but also made the LTWP and land issues in general key campaign issues for the 2017 general elections (Interview_015, Political seat contestant Marsabit County Assembly, interviewed in Marsabit on the 27 April 2017). 


\section{The Politics of Grassroots Mobilisation around LTWP Project}

Understanding local resistance to the LTWP project in the local pastoralists' communities necessitates an exploration of the politics of land as well as the territorialised ethnicity in Kenya's pastoral areas. As "arenas of action", political reactions "from below" [33] to the wind power project were symbolic of the prevailing politics of land in the area which found a clear ideological expression following Kenya's 2013 general elections. The local resistance was made up of two groups (see Table 1), the petitioners (TPs) who brought the case against LTWP project to the ELC on behalf of the indigenous communities in Laisamis Constituency and Karare Ward (Karare Ward, largely inhabited by the Samburu speaking Arial group, is a local electoral area of the Marsabit County under Saku constituency. The local groups have claims to the contested area for dry season grazing as well as cultural affiliations) of Marsabit County, and the interested parties (IPs) who asked to be enjoined to the case to represent the interests of the communities residing in the immediate vicinity of the project. The TPs included elected members of the Marsabit County Assembly drawn from the larger Laisamis Constituency. They represented themselves as "patriotic" Rendille and Samburu leaders who put "communities' interest" before their own and described the IP supporting the continuation of the project as "puppets (of the LTWP project) after individual interest." (Interview_015, Political seat contestant Marsabit County Assembly, interviewed in Marsabit on 27 April 2017). On the other hand, the IPs pictured themselves as "defenders of the local communities rights to development" and claimed that they have "already seen the fruits of this (LTWP project) development" (Interview_025, Interested Party to the LTWP case, interviewed in Nanyuki on the 30 May 2017). While the claim of the wind project's "development contribution" to the region could be easily rationalised by the IPs, they did not dismiss claims of dispossession that have fueled the opposition to the project. For example, according to one of the IPs:

"As an IP, I do not support any illegality in relation to the land acquisition by the company, and that is precisely why we have asked the court to refer the matter of land acquisition for arbitration. There are certainly unanswered questions related to the procedure of land acquisition. This is a procedural issue which can be corrected." (Interview_025, Interested Party to the LTWP case, interviewed in Nanyuki on the 30 May 2017)

The nature of ethnic solidarities that epitomises the control of natural resources in the study area remains fundamental to mobilisation efforts against the LTWP project. Historically, Sarima was used for dry season grazing and cultural rights by the Samburu and the Rendille who are bound together by political alliances, kinship ties and negotiated access to resources to create reciprocity [59] However, while reciprocal access and use rights could be granted to neighboring pastoral communities during periods of droughts, hostility to the Turkana by these groups was attributed to practices in resource use such as "Turkana cut trees and burn charcoal, being less concerned about the environment [59]". Hence, while the historical hegemony over Sarima was with the Samburu and Rendille, conflict over dry season water and pasture with migrating Turkana groups was a common occurrence, particularly between the Samburu and Turkana pastoral groups [60,61]. Hence, ethnic contest over natural resources remains fundamental in the area as it has been for decades. TPs emphasise that the company exploited the history of interethnic conflict in the area to reframe the term "indigenous" in a bid to deemphasise the claims of the "resident" Rendille and Samburu groups over claims of the Turkana "migrants" (Interview_015, Political seat contestant Marsabit County Assembly, interviewed in Marsabit on the 27 April 2017). Specifically, TPs argue that the LTWP project proprietors used the government machinery at national and local levels to "rubber stamp" an illegal land deal (Interview_031, Petitioner, interviewed in Marsabit on the 18 February 2017).

Another issue is the diversity both of the pastoral communities in the area and the interests that often have an ethnic dimension and tend to provoke political mobilisation around land issues. Two aspects of the political history in the area shaped the character of the resistance movement against the LTWP project. First, following the 2010 Kenyan constitution that devolved power to the local 
county level, territorialised ethnicity [62] has emerged and has become greatly politicised, leading to coalition building between ethnic groups towards the 2013 elections. Consequently, the 2013 elections were characterised by alliance-making which also brought about an increased role of customary leaders in Marsabit politics [63] in which the idea that every group had a homeland gained ground. This led to the formation of the Rendille-Gabra-Burji (REGABU) coalition which went on to win the inaugural Marsabit County elections in 2013. This dimension of politics also yielded "power sharing" at the community level where the pursuit of ethnic and clan interests emerged as part of the political discourse. As a result, the Rendille and Samburu ethnic groups dominated the politics of the Laisamis Constituency with steady numerical dominance (4 out of 5 ward representatives from the Constituency in the Marsabit County assembly). The fear of losing "homeland" enhanced the local political leverage of the dominant ethnic groups across Marsabit County and posed a constant fear of displacement for minority tribes (Interview_015, Political seat contestant Marsabit County Assembly, interviewed in Marsabit on the 27 April 2017). Second, the immediate fallout of the 2013 REGABU coalition yielded fresh political realignments for the 2017 elections with an equivocal emphasis on land issues. In the Laisamis Constituency, in particular, land grabbing claims by the LTWP project brought new variations on the political leaders. The main line of confrontation was that political leaders were "either with us, or with the land grabbers (LTWP project)" which was a measure of the 2017 aspirants' degree of "Rendilleness" or "Samburuness" (Interview_031, Petitioner, interviewed in Marsabit on the 18 February 2017). This emphasis enabled an intimate political mobilisation of communities for the 2017 general elections in Laisamis Constituency.

In the midst of these politicisations, the emerging grassroots resistance to the LTWP project was divergent and un-coordinated, reflecting first, the markedly little past experience with challenging the state's development plans and significant challenges in the knowledge and capacity of communities and associated issues of coordination in popular responses to LSLAs [64]. Second, finding a united front to challenge the infringement of communal rights to land was challenged by unequal power relations and conflicts of interest defined along ethnic identity lines that have characterised natural resources politics in the area for decades [65]. Finally, the framing of land rights within the context of the community and the larger social and cultural context (and the fact that all the representatives of the parties to the land suit were men), offers a continuation of cultural bias towards women and the socially constructed gendered roles of women which "affects the processes by which women's and men's differential relationship, access, control, ownership, and security over land are negotiated [66]."

Table 1. Key features of actors in the context of the Lake Turkana Wind Power Project (LTWP) project contestation in the Environment and Land Court (ELC).

\begin{tabular}{|c|c|c|}
\hline Issue & $\begin{array}{c}\text { Petitioners (Representing Laisamis } \\
\text { Constituency and Karare Ward Residents) }\end{array}$ & $\begin{array}{l}\text { Interested Parties (Representing } \\
\text { Loiyangalani Residents) }\end{array}$ \\
\hline $\begin{array}{l}\text { Description/leadership/role } \\
\text { in the case }\end{array}$ & $\begin{array}{l}\text { Local political leaders/local community elites drawn } \\
\text { from the larger Kargi and Karare wards. Part } \\
\text { of/representing disposed communities }\end{array}$ & $\begin{array}{l}\text { Local community elites drawn from the Loiyangalani } \\
\text { area representing the interests of communities living } \\
\text { at the project site }\end{array}$ \\
\hline Key struggle & $\begin{array}{l}\text { Agrarian justice, environmental justice, human } \\
\text { rights/indigenous peoples' rights [33] }\end{array}$ & Right to development \\
\hline Arenas of struggle & $\begin{array}{l}\text { Struggle against land redistribution; struggles in } \\
\text { defense of the commons and struggles against } \\
\text { exploitation; compliance with some relevant global } \\
\text { governance principles (FPIC, UNDRIP) (The } \\
\text { petitioners have specifically taken issue with the } \\
\text { Company's lack of Free, Prior, Informed Consent } \\
\text { (FPIC) and no-adherence to the UN Declaration on } \\
\text { the Rights of Indigenous Peoples (UNDRIP)) }\end{array}$ & $\begin{array}{l}\text { The struggle for incorporation or for the } \\
\text { improvement of the terms of incorporation; struggle } \\
\text { for inclusion; recognition of claims over territory }\end{array}$ \\
\hline
\end{tabular}


Table 1. Cont.

\begin{tabular}{lll}
\hline \multicolumn{1}{c}{ Issue } & \multicolumn{1}{c}{$\begin{array}{c}\text { Petitioners (Representing Laisamis } \\
\text { Constituency and Karare Ward Residents) }\end{array}$} & \multicolumn{1}{c}{$\begin{array}{c}\text { Interested Parties (Representing } \\
\text { Loiyangalani Residents) }\end{array}$} \\
\hline $\begin{array}{l}\text { Preferred form of action on the } \\
\text { LTWP project }\end{array}$ & $\begin{array}{l}\text { That the LTWP be compelled to stop the project to } \\
\text { address issues relating to the legal procedure of land } \\
\text { acquisition, the Environmental and Social Impact } \\
\text { Assessment (ESIA) and the indigenous status of } \\
\text { resident communities }\end{array}$ & $\begin{array}{l}\text { That the LTWP project be continued as the } \\
\text { community has benefitted from the project }\end{array}$ \\
\hline Overarching campaign framework & $\begin{array}{l}\text { Protection of communal land rights, right to } \\
\text { livelihoods and rights to cultural sites }\end{array}$ & $\begin{array}{l}\text { Implicitly for communal land rights; right to } \\
\text { "development" promised by the LTWP project }\end{array}$ \\
\hline Perspective on the project/LSLA & $\begin{array}{l}\text { LTWP project should be "exposed and opposed"; no } \\
\text { space for dialogue and negotiation; should be } \\
\text { "delegitimised" [67] }\end{array}$ & $\begin{array}{l}\text { Dialogue, collaboration and partnership with LTWP } \\
\text { project and other development projects }\end{array}$ \\
\hline $\begin{array}{l}\text { Position on the role of government } \\
\text { local and national) in dispossession }\end{array}$ & Key institution in dispossession of community land & Silent/not clear \\
\hline
\end{tabular}

\section{The Anti-Politics of Wind Power Development}

In response to the popular opposition and legal challenge to their investment, the LTWP project used various mechanisms to circumvent claims of illegal dispossession of communities and irregularities in the process of EIA and community consultation. Despite a lack of strong grassroots resistance to the project, top-down counterresistance was manifested through the actions of government institutions and corporate actors seeking to counterbalance and contain the dominance of communities' claims in their material and symbolic terms. In the socioeconomic context of "political reaction from above", the state-led and private sectors delivered development visions constituting the centerpiece of legitimising dispossession. Here, we define political reactions from above as multipronged strategies and techniques that serve a "state-driven, productive, employment-generating form of national development that enjoyed significant ideological legitimacy" [68], with the aim of making LSLA operations politically and socially feasible. By their very nature, these strategies express a discontent with local livelihoods and related land uses through particular conceptions of viability embodied in technical recommendations on the "economic units" and based on modernisation narratives [7]. The proponents of wind power in Northern Kenya sought to circumvent claims of nonadherence to legal procedures for community land acquisition and the need for international instruments for free informed and prior consent (FPIC) of local indigenous communities. The strategies employed by the corporate actors in LTWP project are highlighted below.

(a) Discursive regimes of representation

The premise of development discourse by the Kenyan government and the corporate actors involved in the LTWP contained in the development blueprint, the Kenya Vision 2030, and extensively reproduced in the LEC, positions the development of the hitherto marginalised north, energy deficiency and visions of affordable green energy as the centerpiece, legitimising exploitation and dispossession which characterised the process of land acquisition for the project. Kenya's 2002 elections not only brought Moi's 24-year rule to a close but also ushered in an era of development visions that sought to identify the key policy actions and reforms with an objective of realising a "higher and sustainable growth of the economy in a more equitable environment, accompanied by increased employment opportunities [69]". Kenya's Vision 2030 resonates with discourses of "frontier economies" and "Africa rising" [5] and a revolutionary character through "modern opportunities for creating wealth (President Uhuru Kenyatta during the ground breaking ceremony for the LTWP Project quoted in Danwatch (2016) [70])", involving "new mindsets and methods, innovative strategies [26]". At the same time, however, these visions derive from and are embedded in the institutional patronages and settings that frame them. These ensuing visions, in addition to recognizing the "obscured but untapped potential" of marginalised areas such as Northern Kenya, also present a construction based on neoliberal ideologies of economic development that seek to correct existing social and economic inequalities through priority investments in infrastructure, energy and land reform. Considering the 
historical evolution of development frames in Kenya, the emergent processes are likely to be less profound and less far-reaching [5].

The framing of the development of Northern Kenya is influenced by "technology transfer approaches, in which 'scientific' farming practices and technologies are provided to help modernise and civilise 'backward' farming systems" [7] and specifically refers to frontier economies as emerging centers of opportunities and engines of growth [71]. In this context, the government discourse is taken up by the corporate actors and positioned as "putting the lands to better use" for the benefit of local communities as well as meeting national development goals. The LTWP attorney stated the following in court proceedings at the March 2016 sitting of the LEC in Meru:

"Mr. Nyaoga told the Court that the respondents and the interested parties recognised the importance of the challenged project. He said that it was a Vision 2030 project. He said that the community had benefited immensely and will continue to benefit (Mr. Nyaoga, advocate for LTWP project. Civil Suit 163 of 2014 (Formerly Nairobi ELC 1330 of 2014) I Kenya Law Reports 2018. Page 11 of 28. http:/ / kenyalaw.org/caselaw/cases/view/130470. Accesses on 29 June 2018)."

"for the first time since independence, the interested parties were seeing the fruits of independence through the challenged project (Mr. Kiprop, advocate for interested parties. Civil Suit 163 of 2014 Kenya Law Reports 2018. Page 11 of 28. http:/ / kenyalaw.org/ caselaw / cases / view /130470. Accesses on 29 June 2018)."

The imperative of generating more energy at lower cost to meet the increased demand for energy in the realisation of the Kenya Vision 2030 as well as reducing energy costs in Kenya, which are higher than those of all regional competitors, is another argument often made to legitimise the project. This discourse supports the admission by Kenya's government of energy insufficiency and the role of more private sector players in the energy sector [69]. The LTWP's discourse on wind power development heavily aligns with energy reliability narratives of Kenya Vision 2030:

"Kenya has developed policies that align with these low emission development strategies (LEDS) outcomes. For example, Kenya Vision 2030 includes a National Climate Change Action Plan highlighting the importance of developing a secure, climate-resilient national grid that can support Kenya's development ambitions. In addition, Kenya's Draft National Energy and Petroleum Policy (2015) aims to ensure an affordable, competitive, sustainable, and reliable supply of energy to meet national development needs at lowest cost, while protecting and conserving the environment."

“These goals are crucial for Kenya's development, as fewer than 50\% of Kenya's population have access to electricity."

"LTWP constructed a $208 \mathrm{~km}$ road from Laisamis to Sarima, which has transformed the transportation network in the area. This has significantly increased access to markets as well as to health care and educational facilities for the local population (WOC (2018). Community projects. https:/ /twp.co.ke/winds-of-change/)."

Moreover, the LTWP portrays wind power development within the green energy discourse validated against a host of standards and certification schemes and international environmental treaties. The project was registered as a Clean Development Mechanism (CDM) project with The United Nations Framework Convention on Climate Change (UNFCCC). Green energy fits within the image of Kenya as being among the countries pursuing low emission development strategies (LES)—countries that grow their economies while reducing GHG emissions [72]. Consequently, Kenya Vision 2030 has a diverse strategy of generating more energy at a lower cost, including exploitation of new sources of renewable energy through legal and policy instruments that aim to ensure an affordable, competitive, sustainable, and reliable supply of energy to meet national development needs at the 
lowest cost, including an emphasis on the need to reduce GHG emissions and encourage the use of renewable energy as a mitigation measure [69]. The LTWP understands and aligns their wind energy activities with this agenda while remaining extra confident of their investment gaining credibility and buy-in from a large cross section of stakeholders. The LTWP's discourse on green energy is clearly linked to the push and established targets for green energy and opportunities arising from their development:

"The electricity generated from LTWP will provide a cost-effective alternative to fossil fuels, decrease dependency on foreign fuel imports, and stabilise prices through reliable generation. Power from LTWP will be sold to the grid at about one-third of the cost of fossil fuel-generated electricity. Additionally, the capacity from LTWP is expected to reduce the country's reliance on fuel imports. These avoided fuel imports are anticipated to save Kenya more than $€ 100$ million (US\$113 million) per year, improving the country's energy security." [72]

This strategy of development visions and green energy discourse is very effective, with LEC noting that the matter before it "involves a massive project". It also involves "weighty issues", noting in addition that the "project is the single largest private investment in Kenya's history" and that "through the Power Purchase Agreement, public funds have been and continue to be utlised (...) The fact that the project is massive appears not to be in dispute [57]". This not only creates favorable conditions for the continuation of the wind power projects despite the "alienation of such expansive piece of community land to a private entity", which amounts to "a contemporary land injustice" [57] but also such discourse depoliticises the wind power development by omitting equally weighty issues related to impacts of the project on local livelihoods, ancestral and cultural heritage and loss of key common pool resources.

(b) The anti-politics of commons governance

The depoliticisation of wind power development by the LTWP has been characterised by a planning process that casts local pastoral livelihoods and communal land use as "unviable" and a need to transform "idle" and "underutlised" land through an efficient infrastructure network, creating an enabling environment for private sector participation and harnessing wind, solar and geothermal energy among other strategies. This not only puts the responsibility of planning, constructing and operating large-scale development programs into the hands of private sector actors but also creates an illusion that state bureaucrats and local institutions are absolved from their responsibility and accountability $[4,73]$ as planners and implementers of economic and social policies. From the time the proposal for the wind farm was put before the Marsabit County Council (MCC), the LTWP investors had a free hand in matters related to land acquisition, making concession agreements and defining which local community groups qualify as "indigenous" and hence qualify for compensation for the wind power project development in the area.

The initial application for the lease of 100 acres of land by the LTWP from the Marsabit County Council was made on 20 November 2006. According to the Trust Lands Act cap 288, which was the applicable law for community land at the time, the MCC was required, upon receipt of such requests, to notify the Divisional Land Board (DLB) or in the case of its absence establish one to meet to consider the proposal, notify people in the concerned area, hear and record submissions from people who were present and submit written recommendations to the council [74]. By the LTWP's own admission, public consultations began a year after their initial application, but no records exist to that effect. More importantly, the said public consultations were neither representative of the Loiyangalani residents, nor did they involve full disclosure of the project, as explained by the attorney representing the communities' interest in the case:

"The only meeting held was attended by town dwellers and fishermen from one area (Loiyangalani) and did not involve the pastoralist community and the project therefore lacks 
public participation in its establishment. This meeting neither declared the size of land required for the project, nor did it inform the community of the loss of access to their land, but instead concentrated on the benefits to the community." [70]

On 13 August 2017, the LTWP's application for a 99-year lease of 150,000 acres of community land was approved. Without a clear response from the MCC on whether the DLB existed at the time of the application and given the scant details of the community consultation carried out for the LTWP's application, the communities denied any knowledge of the project or its application for their land prior to site preparation activities in 2007. In its defense, the LTWP submitted that the instituters of the suit "were not inhabitants of the affected area (...) that one can only have ancestral rights if one was a descendant of known ancestors and a denizen of the apposite area ( . . ) therefore cannot be representing the project affected communities [8]." Consequently, the LTWP invested heavily in legal representation to delegitimise indigenous communities' claims by promoting and actively pursuing an ideologically-charged discourse informed largely by the colonial conception of the communal utilisation of land. In responding to the claims of illegal annexation of community land during the inception of the project in 2007 and subsequent alleged unprocedural acquisition of an additional 110,000 acres of community land, LTWP used frontier imaginations of "idle, unoccupied" land to explain the rationale of dispossession. The following quote from LTWP lawyers at ELC proceedings illustrates this point:

"Mr. Nyaoga (LTPW lawyer) told the court that the land in question in this matter is currently uninhabited. He told the court that this would be made clear if the court visited the suit land. Mr. Nyaoga opined that the community was not merely being left on the roadside (Civil Suit 163 of 2014 (Formerly Nairobi ELC 1330 of 2014) I Kenya Law Reports 2018. Page 14 of 28. http:/ / kenyalaw.org/caselaw/cases/view/130470. Accesses on 29 June 2018)."

More importantly, alongside the lack of community consultation, the LTWP's compensation entitlement of the affected communities' agenda reveals inconsistencies with the Trust Lands Act, drawing attention to instances of 'bribery' involving local political leaders [63]. Attributed largely to the fact that LTWP project designated the land as "empty" and because of its narrow definition of indigenous communities in the area, no compensation was paid. Instead of the mandatory compensation entitlements where community land is acquired, as stipulated in the Trust Lands Act, LTWP employed a predominantly Corporate Social Responsibility (CSR) focus (explored in the next section) that highlights the advantages of investments in community projects. The systematic presentation of CSR as "development gains" for the local community highlights the ways in which transformative CSR investments in infrastructure that support local livelihoods are linked to the LTWP project's wind power development in the area. CSR investments projects are chosen and refined through a "deliberative" process of consultation providing community "validation", perhaps the reason, despite the largely popular opposition to the project, that they remain popular.

Another feature of the LTWP project's development discourse is the conception of "local communities" as a simple agglomeration of "ethnicities" which, according to Ferguson, reduces the complexities relating to resource access and use to the "level of individual 'values', 'attitudes' and 'motivations' [4]." This conception was evident in the planning of the wind power project and in drafting an Indigenous Peoples Policy Framework in 2011, in which LTWP notes:

"It is clear that while most of these tribes are considered marginalised at international, regional and national levels, they have the same chance under this project to voice their concerns if their rights, interest, needs, livelihood, culture or desires are affected (Quoted in Danwatch report "A people in the way of progress")." [70]

In this respect, LTWP's conception of a picture of local communities as merely "ethnically diverse" takes no account of the competitive environments that characterise resource access and entitlement in a CPR system. In ethnically diverse settings, such as the LTWP project site, resource 
access and entitlement can not only accentuate contestation and conflict between ethnic groups but also consequent market integration can lead to rising inequality and declining resource conditions for local livelihoods [75]. Apart from depoliticising natural resource politics and repositioning local ethnic groups as driven by nothing more than individual motivations, these representations assume that LTWP's "same chance under this project to voice their concerns" strategy will be free from social and political contestations inherent in this context.

(c) CSR-greenwashing dispossession

Claims of dispossession and contestation have affected the relationship between the company and the local pastoralist communities and polarised the local political leaders along the lines of ethnicity and whether a specific community supports the project. The combined effect of the representation of local communities and heightened ethnic tensions over the ownership of land in Sarima generated an ingrained antipathy towards the company, which the local communities view as a threat, occasioning economic and social challenges and hardships and "exposing their lives to vagaries of nature (Ibid Page 17-18 of 23)." The LTWP, in return, has sought to counter this antipathy through CSR investments mainly carried out through the Winds of Change (WOC) Foundation to achieve local level legitimacy and challenge the image of its label as a "land grabbing" corporate body. In effect, the CSR strategies seek a "social license to operate (SLO)" to "gain the approval and support of local communities" through "responsible" or "sustainable" management of the adverse social and environmental impacts of corporate activities [76,77] and to achieve legitimacy in their operations [78]. Hence, by establishing and funding the activities of WOC, the LTWP has a stated aim of improving the livelihoods of the communities in the project area (Winds of Change is expected to be funded for a period of 20 years (the operational life of the project) with a contribution of Euro 10 Million. WOC is expected to confine its operations to the Laisamis constituency in Marsabit County). According to the LTWP, the WOC activities will be confined to education and vocational training support, supporting health education and health infrastructure, and provisions of water to improve livelihoods with a shift that emphasises midterm livelihood activities. According to WOC website:

"WOC works in partnership with the county government, local leaders, NGOs, CBOs and government departments in implementing negotiated activities to ensure optimal stakeholder engagement, participation and ownership. WOC aims to catalyse positive sustainable development to enhance livelihoods in the areas surrounding the wind farm (WOC website https://ltwp.co.ke/winds-of-change/)."

For the LTWP, becoming "trusted partners" of local communities is important for two reasons. First, it is instrumental in seeking the recognition of, and, by extension, the legitimacy to operate in the area, through funding "negotiated activities". Basic health and education infrastructure has lagged in the region, and it has had one of the lowest human development indicators in the country [79]. The region, which has experienced increasing populations and associated competition for resources, has also been experiencing increasing droughts that have had constraining effects on the livelihood options and have generated the massive socioeconomic differentiation of households [51,80], significantly alternative livelihood trades, petty businesses and wage labor in the informal sector [81]. In the context of unpredictable weather, investments in education, healthcare and local livelihoods are thought to increase local communities' resilience to drought. To reduce livelihood vulnerabilities and improve the provisioning of basic services in the regions on the margins, development interventions work with and through existing policies that support the provisioning of basic services of education, health and entrepreneurialism [51]. The LTWP's CSR strategy therefore forms the "central core of a layered approach in which each layer relates to specific stakeholders and their associated concerns" [76], which is meant to legitimise the activities of the company in the minds of local communities. According to WOC, 
"It is anticipated that the planned social investment activities will enable LTWP and its project partners to become trusted partners in development with the local community around the wind farm and the larger Laisamis constituency (WOC (2018). Community projects. https://ltwp.co.ke/winds-of-change/)."

This strategy has proved to be very effective, with WOC investing in over 30 projects in the Laisamis Constituency that span the education, health and water sectors. A health center nurse explained the WOC investment in health infrastructure and the implications this has had on the availability of essential drugs and health indictors in the area:

"We never had lights (in the health facility). I was using a spotlight to do deliveries (at night). Now we have a working solar powered lighting system and a delivery bed. We can now store the drugs here safely in this facility. The health indicators are going up (Interview_024_Health Centre Nurse, Video "Insights in to the social footprints of the Lake Turkana Wind Power Project" https://1twp.co.ke/winds-of-change/)."

The appropriation of CSR to obtain SLO by the LTWP in the context of a contestation of its activities can be understood as examples of a "green washing" dispossession. However, as with Loperena's account of similar practices in conservation [82], CSR does not stop the exploitative processes of appropriation by the state and corporate investors set in motion by development visions of the state focused on appropriating natural resources premised on low-cost green energy development. Apart from the fact that CSR activities risk presenting certain business values as non-negotiable universal values and hence overriding the role of business in poverty reduction in the developing world [83], CSR activities, in a context where the state has failed to provide the necessary social amenities, as Ferguson argues, may reinforce and expand "the exercise of bureaucratic state power, which takes poverty as its entry point" in launching an intervention that has adverse effects on local communities [4]. The LTWP's CSR strategies mask the material practices of dispossessions of pastoral communities of their CPRs through CSR investments. The company's CSR investment strategy suggests that there may be important commonalities with past experiences where CSR are not adequately aligned with those of the local livelihoods [83] and do little to redress the pervasive resource conflicts as a result of the degradation and shrinkage of the natural resource base associated with LSLAs for incompatible development projects [84]. These pastoral CPRs are important because they harbor important resources for local people's livelihoods, enabling resilience against complex ecological contexts.

\section{The LTWP's Anti-Politics Machine and Comparative Observations}

The case of the LTWP has played an important part in the discursive process of endorsing and legitimising the development discourse through the reproduction and circulation of their own version of pastoralism representation vis-à-vis wind energy in Northern Kenya. Thus, this section provides a detailed commentary on the theoretical premises of the development representation, together with their institutional rationales through Ferguson's anti-politics machine framework: (1) the context in which anti-politics of dispossession of pastoral commons are constructed, (2) how the anti-politics machine is developed and (3) the key elements of the anti-politics machine, focusing on the articulation of the notions of "development" and "green energy" by the LTWP and the specific ways they are constructed around pastoral land use.

First, the context under which the LTWP has supported and promoted an anti-politics machine involves a complex array of historical and contemporary reproductions of pastoral land regions as "backward" and "emerging" [85]. Historically, pastoral lands have been seen by the colonial states as sites of famine and impoverishment, undermining political stability through forms of rebellion and insurrection [51]. The premise of pastoralism development discourse as an exercise in dealing with "backward, primitive and war-like" nomads through visions and plans entailing "modernity and progress, security and stabilisation" goes back to the colonial project in east Africa that sought to appropriate land for the colonial settlers. The position of the states in postindependence east 
Africa changed very little in its policy discourse about pastoral land use. Apart from being viewed as "unproductive", states have viewed pastoral areas as a threat to the political, security and commercial interests of leading industrialised countries, in effect creating a precarious politics and, with it, top-down development interventions that often take a security dimension [51]. These trends, driven by neoliberal development policies encouraged by the World Bank [86] and bilateral donors, promoted interventions that focus on alternative land uses to pastoralism, including the promotion of private rights in land that not only led to the loss of communal land rights but also encouraged sedentarisation of pastoral populations, which has been associated with impoverishment, resource competition and population pressure $[87,88]$. Thus, even with evidence of massive failures of development interventions based on the incompatibility between modernised interventions and transhumant herders [89], the LTWP project utilises the state policy discourse that emphasises "opening up" marginal areas through large-scale investments in infrastructure and energy projects. Hence, the failure of the LTWP and local governance institutions to adhere to the guidance on stakeholder engagement and FPIC and the subsequent depoliticisation of wind power development in Northern Kenya is linked to a historical development discourse about the viability of pastoralism and communal tenure in the debate on land redistribution.

Second, the way in which the anti-politics machine has been developed within the LTWP's development discourse involves alliance building with state agencies and local elites that is meant to downplay the political character of land redistribution. The processes of land acquisition for the wind power project have been generated less through community consultation established in the law and more so through smaller and select groups of local and national institutions and elite networks. This was described in detail in the defense statements of the LTWP in the ELC:

"He told the court that the first defendant (LTWP project) approached the then County Council of Marsabit with its intention to embark on a wind energy project in 2005. He said that from the year 2005, continuous consultation between the defunct County Council of Marsabit and the local community had taken place. He also told the court that the defunct County Council of Marsabit and the National Government had been in consultations for a period of 9 years." (Records of the ELC proceedings on 8 March 2016 [8])

The key point here is that the processes of land redistribution are partly in continuity with previous interactions between the state and pastoral communities [90], where the state has perpetuated dispossession without regard for legal procedures. In this sense, the LTWP's anti-politics machine relies on being aware of and working within a broader state development discourse on "pastoral life-worlds, politics and resource management [85]."

The core elements of the LTWP's anti-politics machine are representations related to "green energy" development and pastoral land tenure. This discourse serves the dual purpose of representing the transformative impacts of the wind power project on pastoral land on one hand and, on the other, a representation of pastoral land use as "idle" and that needs to be "opened up", a discourse that tends to propagate a depoliticised interpretation of pastoral land tenure and resource governance, which are products of colonial antagonisms towards communal land rights. The LTWP has provided several representations that illustrate the importance of "affordable green energy" for the "development" of the region, creating an interdiscursive process where dispossession of "wasteful" pastoralists and "idle" community land is justified for the greater good of "development". This strategy shifts the focus of grassroots resistance from corporate actors to public institutions, which is presented as a neutral tool for planning and implementing economic policy and is incapable of working against the interests of the people. In constructing its anti-politics machine, the LTWP's strategy of low-cost green energy development is discursively constructed in ways that emphasise the backwardness of the region and the investments required for its transformation, without any mention of the project's social, economic and environmental impacts on the local communities. Once constructed, the anti-politics machine "shapes not only the formation of reports and documents, but the construction of organisations, institutions 
and programs [4]." For instance, the ELC, in referring the case for hearing and determination by a bench of judges, elaborated the court's position:

"A question arises as to whether the alienation and annihilation of the community's ancestral land to the tune of 150,000 acres amounts to an irreparable loss and an unquantifiable inter-generational loss (......) that the project is the single largest private investment in Kenya's history, and that through the Power Purchase Agreement, public funds have been and continue to be utilised (......) The fact that the project is massive appears not to be in dispute. (......) I am inclined to find that the manner in which public funds (which is the tax payers' money) have been used and continue to be used in a project of such great magnitude is an issue of general public importance and of great public interest." [57]

Thus, a discourse is built around government policy on the importance of efficient utilisation of public finances that would support national development. The LTWP's anti-politics machine builds on these efficiency motives and builds a cumulative discourse about how 'low-cost green energy' will benefit national development. This reiterates Ferguson's insightful observation that it is the "promise of real input that makes the "development" form of engagement such a tempting one for many intellectuals [4]." The anti-politics machine not only represents the LTWP as a dutiful private sector player committed to delivering low-cost green energy but is also charged with the task of empowering the region's economically marginalised poor.

Complicating matters is the fact that community opposition to the LTWP reflected ethnicity-centered relations in the area. The litigants in the ELC case against the LTWP were mainly drawn from Rendille and Samburu pastoral groups that claimed the project was not only going to affect their livelihoods through reduced access to dry season pastures but would also reduce access to ancient ancestral sites for cultural rituals (Important cultural ceremonies of the Rendille and the Samburu include initiation rituals, galgulame-a gathering of all Rendille clans once in 14 years, a year after the circumcision ceremony. For a detailed description, see Schlee (1989) [91]). The LTWP's articulation of "community" in the area was drawn from a narrow definition as follows:

"Sarima village is the only village located on the wind farm. The ESIA process established that the location of Sarima village on the C-77 road would pose health and safety risks to the community from increased road traffic during the project's construction phase." [92]

Under the company's own admission, the Turkana population in the area only settled at the project site in the mid-2000s—-the same time the project was initiated-after experiencing heightened conflicts in Turkana County [92]. This trend has been manifesting in the pastoral areas of the Horn of Africa, where Goldsmith [93] observed that high rates of demographic growth and contested rights because of uneven capitalists' transitions in the region are leading to conflicts. Similar dynamics have been observed in Northern Kenya [94] and Southern Ethiopia [85], where economic incorporation is promoting new forms of criminality and the politicisation of kinship relations, respectively. This, according to Hagmann and Mulugeta, is a characteristic trend of the securitisation of development projects in pastoral areas, where a section of the local community or group or their local leaders is coopted to uphold security and state interests at the local level [85]. In the case of the LTWP, the illustration of Sarima as the "only village located in the wind farm" has not only excluded the larger pastoralist communities dependent on the region for livelihood and cultural reasons but also served to redefine ethnic communities competing for benefits from the project. According to a local NGO,

"The company (LTWP) seems to adopt a de facto policy of encouraging the Turkana to settle on a land that is not clearly theirs. First, they denied the Rendille and the Samburu who are the real owners of this land their rights for 'living far from Serima'. Then, they claim the same pastoral land tenure allowed the Turkana to own land that doesn't belong to them (even though the company acknowledges Turkana's settled here in the 2000s). The selective representations of pastoral land tenure points to just how dishonest this whole arrangement is." (Interview_013_Local NGO representative interview in Nairobi, 7 May 2017) 
Likewise, in terms of CSR investments, the WOC newsletter has been an important avenue through which to disseminate the work carried out by the company that benefits the local community from the project through the commitment to "invest a portion of its operating revenues to WOC to improve the livelihoods of the communities in the project area" [95]. These types of striking selective representations of local communities by the LTWP have provoked differing reactions from the local communities, some of which have asked to be enjoined in the suit against the company as "interested parties" that can attest to the benefits of the investment to the local areas but also legitimise the company's discourse on pastoral land tenure. Through their attorney, the interested parties, who are the residents of Loiyangalani District, argued that:

"the proposed interested parties were the ones directly affected by the project. He said that they had been consulted in all matters concerning the challenged project and that the consultations started around 2005.... the plaintiffs/applicants were strangers. He said that for the first time since independence, the interested parties were seeing the fruits of independence through the challenged project.... (they implored the court) to maintain the status quo (Civil Suit 163 of 2014 (Formerly Nairobi ELC 1330 of 2014) I Kenya Law Reports 2018: Page 20 of 23. http:/ / kenyalaw.org/caselaw/cases/view/130470. Accesses on 29 June 2018)."

Under this discourse, the frequent selective representation of pastoral commons by the LTWP has a reiterative effect that is important in the establishment and perpetuation of the anti-politics machine. This discourse can also be read beyond the company's CSR activities and understood in terms of the representation of ethnic ascriptions and ethnicity as "economic assets in a development process" [96] within ethnically mixed settings.

In sum, the LTWP is the key actor in the wind power development in Northern Kenya, in terms of constructing, sustaining and reproducing the anti-politics machine that this paper has identified. This contribution has identified the reproduction of historical misconceptions about pastoral land tenure "progressively governmentalised" $[4,97]$ by the bureaucratic state institutions, but also found the specific knots of depoliticisation of development interventions conceived, implanted and legitimised by the LTWP. Its reproduction of the Kenyan state's discourse on key discursive elements, such as 'low-cost green energy' and representations of pastural land tenure, not only guarantees continuity with previous interactions between the state and pastoral communities largely experienced in the east African region $[85,90]$ but also shapes the larger mechanisms through which such misconceptions are produced and reproduced in development interventions. In this way, the LTWP's anti-politics machine provides a medium for the expansion and depoliticisation of state development visions. The Vision 2030 and its flagship project - the LTWP project-have provided an apparently technical and apolitical entry point for an intervention that largely dispossesses communities of their land.

The analyses in this paper provide insights into the extent to which the processes of depoliticised development discourse identified in this single Kenyan case operate in other pastoral commons development contexts. Certainly, there are a lot of context-specific factors that are particular to the Kenyan case presented in this paper that limit the generalisability of this case study to other similar contexts. For instance, unlike the exclusion of communities in land acquisition in the Kenyan case, in Ghana customary authorities were proactively engaged by a private company in the process of land acquisition and benefit sharing in a biofuel plantation project without any government intermediaries [98]. Other experiences across similar LSLAs in Kenya and similar African contexts indicate that the pattern of grassroots mobilisation is not always necessarily one of "expose and oppose" as it was with the LTWP project case, but of attempting to ensure greater inclusion, incorporating the improvement of the terms of incorporation and recognition of claims over territory. For instance, the case of overt protest by the local Turkana community against the oil exploration company Tullow Oil Kenya sought more jobs for the local community members and a bigger share of the oil revenue to the region [5]. However, there are similarity factors that support the view that some degree of generalisability may be possible from the case of LTWP project in Kenya. 
In post-colonial Africa, the persistence and centrality of mobility and communal land ownership were associated with "the tragedy of commons" [21] which governments in Africa used as justification for taking away rights and responsibilities related to resources out of the hands of local communities [99]. Further, communal land has been pointed to by state development policies in developing countries as evidence of "marginal", "empty" and "available" for alternative development $[42,100,101]$. These categorisations of pastoral land use and common property rights have become key operational mechanisms through which land-use changes are facilitated [102]. Hence, many development visions for the "development" of pastoral commons remain remarkably uniform and standardised, as illustrated by cases from Africa pastoral commons, both generally $[2,39,64,100]$ and specifically in among pastoral commons in Ethiopia [6,103-105], and west Africa nations [106]. These examples are illustrative of the fact that the Kenyan case shows similarities to other practice associated with depoliticised representation of pastoral commons in very different contexts and therefore does not seem to be an exception.

Another aspect which could influence the generalisability of the Kenyan case is ideological underpinning of transformative development policies which is "premised on a classic conception of modernisation, which presumes a steady decline in the share of agriculture in the national income and in the composition of the labour force" where pastoral communities "constitute a vast reservoir of backwardness and a structural impediment to economic modernization [6]." The process of "development by dispossession" shows continuities with historical processes of dispossession across the world [107] with the vulnerability of lands to dispossession being highly correlated with the extent to which local and international legal systems recognise the multiple values that society attaches to land [42]. The Kenyan legal situation of communal tenure (especially prior to the 2010 constitution) is similar to that of many other countries where the proprietary character of the commons has been denied by both colonial and post-colonial administrations [108] and classified as "wastelands" and legally fully disposable by the state at its will [2]. These trends in the historical dispossession of pastoral commons and the role of weak legal recognition show strong resemblance across pastoral populations beyond the Kenyan case.

Finally, CSR activities, the central focus of the corporate anti-politics machine, constitute the discursive logic of assuming away and rendering unproblematic the depoliticisation of development interventions. This strategy of "greenwashing dispossession" [109] and "engineering consent" [110] is not unique either to the Kenyan case or commons dispossession; similar experiences have been observed in African contexts and globally in different sectors of LSLAs, such as agriculture, mining, energy and infrastructure [111]. CSR investments are thus an inevitable characteristic of LSLAs deployed to make development interventions politically feasible in the face of determined political mobilisation from affected communities.

\section{Conclusions}

This study has unveiled the anti-politics machine in the relationship between development visions and accompanying LSLA programs and the dispossession of pastoral commons in the current LSLA in Kenya. The analysis of the LTWP revealed that there is more to the recent discourse on the development of wind power in Northern Kenya than the imperative of generating more energy at lower cost to meet the increased demand in the realisation of Kenya Vision 2030. Drawing on Ferguson's anti-politics machine, the paper has shown that development visions of the hitherto marginalised Northern Kenya and their focus on large-scale infrastructure and energy programs are contingent upon the construction of ASAL livelihoods as unviable-a dominant colonial and postcolonial discourse that legitimises alternative large-scale investments as the ideal. Accompanying practices, such as placing the responsibility for the planning and operation of LSLA programs into the hands of private sector actors that attempt to absolve state and local institutions from their responsibility and accountability projects, legitimises the depoliticisation of development programs to secure the extraction of value from natural resources by the private sector. LSLAs are constructed as the necessary interventions required to bring 
the isolated ASALs to integration with the national economy, excluding local pastoral livelihoods from being recognised as viable investment options to economic development. This representation, through discourses, technical recommendations, institutional apparatuses and apolitical interventions, forms the anti-politics machine that depoliticises important realities that characterise CPR use and governance and makes them amenable to solutions that may have no effect on their sustainable development but instead have undesirable results. As Agrawal argues,

"Without attention to the politics that generates underdevelopment and environmental degradation as universal problems, it may be impossible to address poverty, underdevelopment, and environmental degradation effectively." [112]

This anti-politics machine has the undesired effect of prioritising natural resource appropriation for national development goals over local priorities for them. In the LTWP case, the state and its network of corporate actors and local elites uncritically endorse the acquisition of community land for wind power development through a process that plays down the significance of the inherent complexities of CPR use and governance and their contestations related to disproportionate access and control by local communities. This is achieved through the anti-politics machinery that enables the implicit reproduction of historical misconceptions about pastoralism and communal tenure to legitimise the alleged irregular acquisition of community land.

To build on the concept of an anti-politics machine and its role in dispossession of commons, putting some of our findings in perspective is necessary. The case of the LTWP project is emblematic of the depoliticisation of new development visions involving the opening of frontier borderlands as new sites for the investments needed for growth of the national economy. Although these development visions involve strategies promulgated by the state, they involve a broad range of actors and a combination of public and private finance and governance [64] through public-private partnerships [113]. The contingent nature of these development visions as "arenas of action" relies on what Scott refers to as "state simplification" processes involving the reorganisation of natural resources for easy manipulation by the state and the uncritical optimism in the possibilities of planning through which state development policies were facilitated. This means that the private sectors actors with the vital role of delivering these development visions have a high degree of political power within these arenas of action and may, and often do, engage in a depoliticised partnership with the state. In this context, unveiling the anti-politics machine strategies employed in development visions involving public-private partnerships is key to understanding how private capital is involved in the distribution, multiplication and intensification of state power [4]. This is particularly the case for renewable energy systems built to further capital accumulation [114], where private capital with the technical solutions and capital drives the agenda for the implementation of environmentally friendly technologies for energy production.

Further, the paper has shown that common assumptions in development discourses promoting LSLAs involving public-private partnerships promote a depoliticised representation of local communities and oversimplification of competing interests and power structures at multiple levels. The depoliticised discourse, as Ferguson argues, "provides the technical point of entry" [4] for an intervention serving the political interests of corporate actors. However, the LTWP project's anti-politics machine is certainly not the source of the depoliticising discourse and strategy but rather, as Ferguson argues, one among the links in the mechanism that produces and articulates it [4]. Even more importantly, the logic of the LTWP project's anti-politics machine draws from the (mis)representations inherent in the state's own development discourse that have characterised ASALs development since colonial times. As a result, these misrepresentations often bring to the fore state-centric notions of the understanding of viability of marginal lands, such as the ASALs "powerfully informed by ideas about efficiency derived from neo-classical economics, and is rooted in the dominance of a particular type of commercial farming" [7] which lays the justification for alternative investments in land which serves the goal of "reinforcing and expanding the exercise of bureaucratic state power [4]." In the case study presented in this paper, the dominant storyline by the TP regarding the role of the wind 
project in dispossessing communities through irregular acquisition of their land is ceding ground to one, advanced by the LTWP project and its network of government institutions, that transcends the logic of dispossession-generating low-cost green energy and the contribution of the project to the regions development through infrastructure that will connect the hitherto marginalised region to the rest of Kenya. Consequently, legal protection and judicial support sought by the communities affected often "veers away from questioning the fundamental roots of land-grabbing...while engaging in the problematic notion of win-win scenarios [113]."

The case of the LTWP illustrates some of the tensions between land redistribution and depoliticising development discourse about ambitious development interventions that have been a characteristic occurrence in Kenya's ASALs. However, the LTWP is not the only case, and indeed, there are several examples of comparable cases where indigenous peoples and local communities were dispossessed of their communal lands without industry guidance on stakeholder engagement and FPIC $[47,103]$. Beyond the likely dispossession of commons, depoliticisation has influenced debates and outcomes on compensations to communities affected by land redistribution apparatuses and ethnic tensions. The depoliticisation of land redistribution for private sector-led interventions carried out under the "progressivist and triumphal banners of development" [115] has already had far-reaching effects on pastoral commons; it leads to the development of exploitative relationships between corporations and communities through the concomitant restructuring of CPR governance and to associated losses of important pasture and migration resources through the erosion of CPRs [116]. This challenges the resilient use of the pastoral rangelands, decreasing the potential for innovatory husbandry [115] and effectively constituting "resilience grabbing". The broad distribution of CPRs and the existence of customary rules that guarantee use rights to communities mediated through an inclusive process of management has given pastoral commons a unique resilience against unpredictability and spatial and temporal distributions across the pastoral rangelands. Land investments that extinguish use and access to critical dry season resources that enable transhumance and offset drought risk [117] and the erosion of an associated institutional design that ensures excludability and addresses the problems of subtractability [40] by extension actually generate greater vulnerability and poverty.

This paper has shown how seemingly simple technical solutions in "development visions" and accompanying public-private partnerships in Kenya employ a depoliticised representation of local realities in the ASALs, aimed at reinforcing historical ghettoisation of pastoralism and communal land tenure. However, considering the specificity of the Kenyan case, important questions not addressed in this paper include the following: Is the corporate anti-politics machine dynamic and relational or static? How is re-politicisation negotiated and with what impacts? This work indicates the need for further research on how the anti-politics machine may be differently generated and negotiated in the context of development visions.

Funding: This research was funded by Schweizerischer Nationalfonds zur Förderung der Wissenschaftlichen Forschung grant number P1BEP1_175227.

Conflicts of Interest: The author declare no conflict of interest.

\section{References}

1. Cotula, L. The International Political Economy of the Global Land Rush: A Critical Appraisal of Trends, Scale, Geography and Drivers. In The New Enclosures: Critical Perspectives on Corporate Land Deals; Routledge: London, UK, 2013; pp. 43-74.

2. Wily, L.A. The Law Is to Blame: The Vulnerable Status of Common Property Rights in Sub-Saharan Africa. Dev. Chang. 2011, 42, 733-757. [CrossRef]

3. Devine, J.A. Community Forest Concessionaires: Resisting Green Grabs and Producing Political Subjects in Guatemala. J. Peasant Stud. 2018, 45, 565-584. [CrossRef]

4. Ferguson, J. The Anti-Politics Machine: Development, Depoliticisation and Bureaucratic Power in Lesotho, 2nd ed.; University of Minnesota: Minneapolis, MN, USA, 1994. 
5. Mosley, J.; Watson, E.E. Frontier Transformations: Development Visions, Spaces and Processes in Northern Kenya and Southern Ethiopia. J. East. Afr. Stud. 2016, 10, 452-475. [CrossRef]

6. Makki, F. Development by Dispossession: Terra Nullius and the Social-Ecology of New Enclosures in Ethiopia. Rural Sociol. 2014, 79, 79-103. [CrossRef]

7. Cousins, B.; Scoones, I. Contested Paradigms of 'Viability' in Redistributive Land Reform: Perspectives from Southern Africa. J. Peasant Stud. 2010, 37, 31-66. [CrossRef]

8. Republic of Kenya. Civil Suit No 163 Of 2014 (Formerly Nairobi ELC No.1330 Of 2014); Government of the Republic of Kenya: Nairobi, Kenya, 2016.

9. Krätli, S.; Monimart, M.; Swift, J. FAO's and IFAD's Engagement in Pastoral Development Joint Evaluation Synthesis; IFAD/FAO: Rome, Italy, 2016. Available online: https:/ / www.google.com.hk/url?sa=t\&rct=j\& $\mathrm{q}=\&$ esrc $=$ s\&source $=$ web\&cd=2\&ved=2ahUKEwjRhoDY1NDfAhVGx4UKHSPqCQ0QFjABegQIDBAC\&

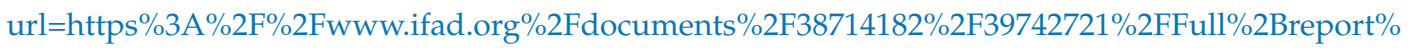
2B\%2528final\%2B-\%2Bunedited \%2Bversion\%2529\%2Fc12e63d6-1794-4752-b0cb-a3ba974c5e53\&usg= AOvVaw25iPebpuzagDam7_mtkUxk (accessed on 22 October 2018).

10. Van den Brink, R.J.E. Consensus, Confusion, and Controversy: Selected Land Reform Issues in Sub-Saharan Africa; World Bank Publications: Washington, DC, USA, 2005; p. 1.

11. Hickey, S. The Politics of Protecting the Poorest: Moving beyond the "Anti-Politics Machine"? Political Geogr. 2009, 28, 473-483. [CrossRef]

12. Büscher, B. Anti-politics as Political Strategy: Neoliberalism and Transfrontier Conservation in Southern Africa. Dev. Chang. 2010, 41, 29-51. [CrossRef]

13. Hirschmann, D. Review. J. Mod. Afr. Stud. 1990, 28, 706-707. [CrossRef]

14. Li, T.M. Compromising Power: Development, Culture, and Rule in Indonesia. Cult. Anthropol. 1999, 14, 295-322. [CrossRef]

15. Zwanenberg, R.M.A.V. The Economic Response of Kenya Africans to European Settlement, 1903-1939. In Politics and Nationalism in Colonial Kenya; Ogot, B.A., Ed.; East African Publishing House: Nairobi, Kenya, 1972.

16. Waller, R. Pastoral Production in Colonial Kenya: Lessons from the Past? Afr. Stud. Rev. 2012, 55, 1-27. [CrossRef]

17. Ahmed, A.G.M.; Ati, H.A.A. Introduction. In Managing Scarcity: Human Adaptation in East African Drylands; Ahmed, A.G.M., Ahmed, M., Ibrahim, A.R.A., Yesuf, A.S., Tewodros, A., Eds.; OSSREA: Addis Ababa, Ethiopia, 1995; pp. 1-6.

18. Home, R. 'Culturally Unsuited to Property Rights?' Colonial Land Laws and African Societies. J. Law Soc. 2013, 40, 403-419. [CrossRef]

19. Markakis, J. Pastoralism on the Margin; Minority Rights Group International: London, UK, 2004.

20. Herskovits, M.J. The Cattle Complex in East Africa. Am. Anthropol. 1926, 28, 230-272. [CrossRef]

21. Hardin, G. The Tragedy of the Commons*. J. Nat. Resour. Policy Res. 1968, 1, 243-253. [CrossRef]

22. Elmi, M.; Birch, I. Creating Policy Space for Pastoralism in Kenya; Futures Agriculture Working Paper 068; Future Agricultures Consortium: London, UK, 2013.

23. Smalley, R. Agricultural Growth Corridors on the Eastern Seaboard of Africa: An Overview. APRA Working Paper Series. 2017. Available online: http:/ /opendocs.ids.ac.uk/opendocs/handle/123456789/13564 (accessed on 22 October 2018).

24. Weng, L.; Boedhihartono, A.K.; Dirks, P.H.; Dixon, J.; Lubis, M.I.; Sayer, J.A. Mineral Industries, Growth Corridors and Agricultural Development in Africa. Glob. Food Secur. 2013, 2, 195-202. [CrossRef]

25. Laurance, W.F.; Clements, G.R.; Sloan, S.; O'Connell, C.S.; Mueller, N.D.; Goosem, M.; Venter, O.; Edwards, D.P.; Phalan, B.; Balmford, A. A Global Strategy for Road Building. Nature 2014, 513, $229-232$. [CrossRef] [PubMed]

26. Republic of Kenya. Sessional Paper No. 8 of 2012 on the National Policy for the Sustainable Development of Northern Kenya and Other Arid Lands: Releasing Our Full Potential; Ministry of State for Development of Northern Kenya and Other Arid Lands: Nairobi, Kenya, 2012.

27. Szeman, I.; Diamanti, J. Beyond Petroculture: Strategies for a Left Energy Transition. Can. Dimens. 2017. Available online: https: / / canadiandimension.com/articles/view / beyond-petroculture-strategies-for-a-leftenergy-transition (accessed on 22 October 2018). 
28. Jasanoff, S. Just Transitions: A Humble Approach to Global Energy Futures. Energy Res. Soc. Sci. 2018, 35, 11-14. [CrossRef]

29. Chassot, S.; Hampl, N.; Wüstenhagen, R. When Energy Policy Meets Free-Market Capitalists: The Moderating Influence of Worldviews on Risk Perception and Renewable Energy Investment Decisions. Energy Res. Soc. Sci. 2014, 3, 143-151. [CrossRef]

30. UN General Assembly. Transforming Our World: The 2030 Agenda for Sustainable Development; UN: New York, NY, USA, 2015.

31. Rulli, M.C.; Saviori, A.; D'Odorico, P. Global Land and Water Grabbing. Proc. Natl. Acad. Sci. USA 2013, 110, 892-897. [CrossRef]

32. Dunlap, A. Counterinsurgency for Wind Energy: The Bíi Hioxo Wind Park in Juchitán, Mexico. J. Peasant Stud. 2018, 45, 630-652. [CrossRef]

33. Borras, S.M., Jr.; Franco, J.C. Global Land Grabbing and Political Reactions 'from Below'. Third World Q. 2013, 34, 1723-1747. [CrossRef]

34. Hall, R.; Edelman, M.; Borras, S.M., Jr.; Scoones, I.; White, B.; Wolford, W. Resistance, Acquiescence or Incorporation? An Introduction to Land Grabbing and Political Reactions 'from Below'. J. Peasant Stud. 2015, 42, 467-488.

35. Gingembre, M. Resistance or Participation? Fighting against Corporate Land Access amid Political Uncertainty in Madagascar. J. Peasant Stud. 2015, 42, 561-584. [CrossRef]

36. Moreda, T. Listening to Their Silence? The Political Reaction of Affected Communities to Large-Scale Land Acquisitions: Insights from Ethiopia. J. Peasant Stud. 2015, 42, 517-539. [CrossRef]

37. Bridge, G.; Bouzarovski, S.; Bradshaw, M.; Eyre, N. Geographies of Energy Transition: Space, Place and the Low-Carbon Economy. Energy Policy 2013, 53, 331-340. [CrossRef]

38. Scheidel, A.; Sorman, A.H. Energy Transitions and the Global Land Rush: Ultimate Drivers and Persistent Consequences. Glob. Environ. Chang. 2012, 22, 588-595. [CrossRef]

39. Alden Wily, L. The Tragedy of Public Lands: The Fate of the Commons under Global Commercial Pressure. 2011. Available online: http:/ / www.landcoalition.org/sites/default/files/documents/resources/WILY_ Commons_web_11.03.11.pdf (accessed on 22 October 2018).

40. Haller, T. The Contested Floodplain: Institutional Change of the Commons in the Kafue Flats, Zambia; Lexington Books: Plymouth, UK, 2013.

41. Brondizio, E.S.; Le Tourneau, F.-M. Environmental Governance for All. Science 2016, 352, $1272-1273$. [CrossRef] [PubMed]

42. Cotula, L. The New Enclosures? Polanyi, International Investment Law and the Global Land Rush. Third World Q. 2013, 34, 1605-1629. [CrossRef]

43. Enns, C. Mobilizing Research on Africa's Development Corridors. Geoforum 2018, 88, 105-108. [CrossRef]

44. Nel, A.; Hill, D. Constructing Walls of Carbon-The Complexities of Community, Carbon Sequestration and Protected Areas in Uganda. J. Contemp. Afr. Stud. 2013, 31, 421-440. [CrossRef]

45. Browne, A. LAPSSET: The History and Politics of an Eastern African Megaproject; Rift Valley Institute: London, UK, 2018.

46. Letai, J.; Tiampati, M. Capturing Benefits Whilst Safeguarding Livelihoods: The Debate over LAPSSET. In Disaster Risk Reduction: East and Central Africa; 2015; pp. 1-3. Available online: www.dlci-hoa.org/ download / capturing-benefits-whilst-safeguarding-livelihoods-the-debate-over-lapsset $/$ ?wpdmdl=3514 (accessed on 22 October 2018).

47. Abbink, J. 'Land to the Foreigners': Economic, Legal, and Socio-Cultural Aspects of New Land Acquisition Schemes in Ethiopia. J. Contemp. Afr. Stud. 2011, 29, 513-535. [CrossRef]

48. Oya, C. Methodological Reflections on 'Land Grab' Databases and the 'Land Grab' Literature 'Rush'. J. Peasant Stud. 2013, 40, 503-520. [CrossRef]

49. KPHC. Kenya Population and Housing Census (KPHC) 2009; Central Bureau of Statistics: Nairobi, Kenya, 2009.

50. Marsabit County Government. Revised First Marsabit County Integrated Development Plan (CIDP) 2013-2017; Marsabit County Government: Marsabit, Kenya, 2013.

51. Catley, A.; Lind, J.; Scoones, I. Development at the Margins: Pastoralism in the Horn of Africa. In Pastoralism and Development in Africa: Dynamic Change at the Margins; Routledge: Abingdon, UK, 2013; pp. 1-26.

52. Republic of Kenya. Vision 2030 Development Strategy for Northern Kenya and Other Arid Lands; Government of the Republic of Kenya: Nairobi, Kenya, 2012. 
53. Lake Turkana Wind Power (LTWP). Providing reliable, low cost energy to Kenya. Available online: https: / /ltwp.co.ke/overview / (accessed on 22 October 2018).

54. Dodd, J. World Bank withdraws support for Lake Turkana Wind Power project. Available online: https: / / www.windpowermonthly.com/article/1156128/world-bank-withdraws-support-lake-turkanawind-power-project (accessed on 22 October 2018).

55. Danwatch. A PEOPLE IN THE WAY OF PROGRESS. 2016. Available online: https://old.danwatch.dk/ undersogelse/a-people-in-the-way-of-progress / (accessed on 22 October 2018).

56. Takouleu, J.M. AFRICA: Finland will invest $€ 114$ million in wind energy, through IFC. Available online: https: / / www.afrik21.africa/en/africa-finland-will-invest-e114-million-in-wind-energy-through-ifc/ (accessed on 22 October 2018).

57. Kenya Law Reports. In Case No. 163 of 2014 Mohamud Iltarakwa Kochale \& 5 Others v Lake Turkana Wind Power Ltd. \& 9 Others [2018]; Government of the Republic of Kenya: Nairobi, Kenya, 2018.

58. Cormack, Z.; Kurewa, A. The Changing Value of Land in Northern Kenya: The Case of Lake Turkana Wind Power. Crit. Afr. Stud. 2018, 10, 89-107. [CrossRef]

59. Oba, G. The Importance of Pastoralists' Indigenous Coping Strategies for Planning Drought Management in the Arid Zone of Kenya. Nomadic Peoples 2001, 5, 89-119. [CrossRef]

60. Fratkin, E. East African Pastoralism in Transition: Maasai, Boran, and Rendille Cases. Afr. Stud. Rev. 2001, 44, 1-25. [CrossRef]

61. Fratkin, E. Pastoral Land Tenure in Kenya: Maasai, Samburu, Boran, and Rendille Experiences, 1950-1990 on JSTOR. Nomadic Peoples 1994, 34, 55-68.

62. Schlee, G.; Shongolo, A. Pastoralism and Politics in Northern Kenya and Southern Ethiopia; James Currey: Woodbridge, Suffolk, 2012.

63. Czuba, K. Ethnic Politics in Marsabit; University of Toronto: Toronto, ON, Canada, 2017.

64. Cotula, L.; Vermeulen, S.; Leonard, R.; Keeley, J. Land Grab or Development Opportunity? Agricultural Investment and International Land Deals in Africa; IIED/FAO/IFAD: London, UK; Rome, Italy, 2009.

65. Klopp, J.M. Can Moral Ethnicity Trump Political Tribalism? The Struggle for Land and Nation in Kenya. Afr. Stud. 2002, 61, 269-294. [CrossRef]

66. Verma, R. Land Grabs, Power, and Gender in East and Southern Africa: So, What's New? Fem. Econ. 2014, 20, 52-75. [CrossRef]

67. Borras, S.M. The Politics of Transnational Agrarian Movements. Dev. Chang. 2010, 41, 771-803. [CrossRef]

68. Levien, M. Regimes of Dispossession: From Steel Towns to Special Economic Zones. Dev. Chang. 2013, 44, 381-407. [CrossRef]

69. Government of Kenya. Kenya Vision 2030; The Government of Kenya: Nairobi, Kenya, 2007.

70. Voller, L.; Christensen, A.B.; Kamadi, G.; Rahman, H.; van de Wiel, H. People in the Way of Progress. Available online: https:/ / old.danwatch.dk/undersogelse/a-people-in-the-way-of-progress/ (accessed on 22 October 2018).

71. Kochore, H.H. The Road to Kenya: Visions, Expectations and Anxieties around New Infrastructure Development in Northern Kenya. J. East. Afr. Stud. 2016, 10, 494-510. [CrossRef]

72. Cookson, P.; Kuna, J.; Golla, E. Benefits of Low Emission Development Strategies. In The Case of Kenya's Lake Turkana Wind Power Project; ICF: Lexington, KY, USA, 2017. Available online: https: / www.africaportal.org/publications / benefits-of-low-emission-development-strategies-thecase-of-kenyas-lake-turkana-wind-power-project/ (accessed on 22 October 2018).

73. Huber, A.; Joshi, D. Hydropower, Anti-Politics, and the Opening of New Political Spaces in the Eastern Himalayas. World Dev. 2015, 76, 13-25. [CrossRef]

74. Kenya Law Reports. In The Trust Land Act Chapter 288; Government of the Republic of Kenya: Nairobi, Kenya, 2009.

75. Tucker, C.M.; Randolph, J.C.; Castellanos, E.J. Institutions, Biophysical Factors and History: An Integrative Analysis of Private and Common Property Forests in Guatemala and Honduras. Hum. Ecol. 2007, 35, 259-274. [CrossRef]

76. Parsons, R.; Lacey, J.; Moffat, K. Maintaining Legitimacy of a Contested Practice: How the Minerals Industry Understands Its 'Social Licence to Operate'. Resour. Policy 2014, 41, 83-90. [CrossRef]

77. Gunningham, N.; Kagan, R.A.; Thornton, D. Social License and Environmental Protection: Why Businesses Go Beyond Compliance. Law Soc. Inq. 2004, 29, 307-341. [CrossRef] 
78. Darling, P. SME Mining Engineering Handbook, 3rd ed.; Society for Mining, Mettalurgy and Exploration Inc.: Englewood, CO, USA, 2011.

79. UNDP. Kenya Human Development Report 2013: Climate Change and Human Development: Harnessing Emerging Opportunities. 2013. Available online: http://hdr.undp.org/sites/default/files/knhd_report_2013.pdf (accessed on 22 October 2018).

80. Letai, J.; Lind, J. Squeezed from All Sides: Changing Resource Tenure and Pastoralist Innovation on the Laikipia Plateau, Kenya. In Pastoralism and Development in Africa: Dynamic Change at the Margins; Catley, A., Lind, J., Scoones, I., Eds.; Routledge: Abingdon, UK, 2013; pp. 164-176.

81. Fratkin, E.M. Seeking Alternative Livelihoods in Pastoral Areas. In Pastoralism and Development in Africa: Dynamic Change at the Margins; Routledge: New York, NY, USA, 2013; pp. 197-205.

82. Loperena, C.A. Conservation by Racialized Dispossession: The Making of an Eco-Destination on Honduras's North Coast. Geoforum 2016, 69, 184-193. [CrossRef]

83. Blowfield, M. Corporate Social Responsibility: Reinventing the Meaning of Development? Int. Aff. 2005, 81, 515-524. [CrossRef]

84. Peluso, N.L.; Lund, C. New Frontiers of Land Control: Introduction. J. Peasant Stud. 2011, 38, 667-681. [CrossRef]

85. Hagmann, T.; Mulugeta, A. Pastoral Conflicts and State-Building in the Ethiopian Lowlands. Afr. Spectr. 2008, 43, 19-37.

86. De Haan, C. An Overview of the World Bank's Involvement in Pastoral Development; Overseas Development Institute: London, UK, 1994.

87. Hogg, R. The New Pastoralism-Poverty and Dependency in Northern Kenya. Africa 1986, 56, 319-333. [CrossRef]

88. Fratkin, E.; Roth, E.A.; Nathan, M.A. Pastoral Sedentarization and Its Effects on Children's Diet, Health, and Growth among Rendille of Northern Kenya. Hum. Ecol. 2004, 32, 531-559. [CrossRef]

89. Meir, A. Nomads and the State: The Spatial Dynamics of Centrifugal and Centripetal Forces among the Israeli Negev Bedouin. Political Geogr. Q. 1988, 7, 251-270. [CrossRef]

90. Mwangi, E. The Footprints of History: Path Dependence in the Transformation of Property Rights in Kenya's Maasailand. J. Inst. Econ. 2006, 2, 157-180. [CrossRef]

91. Schlee, G. Identities on the Move: Clanship and Pastoralism in Northern Kenya; Manchester University Press: Manchester, UK, 1989.

92. Lake Turkana Wind Power (LTWP). Sarima Village Resettlement Process Information Document. Available online: https:/ /ltwp.co.ke/newsite/wp-content/uploads / 20170921-Sarima-Village-Resettlement-ProcessNTS-FINAL.pdf (accessed on 28 June 2018).

93. Goldsmith, P. The Future of Pastoralist Conflict in the Horn of Africa. In Pastoralism and Development in Africa. Dynamic Change at the Margins; Catley, A., Lind, J., Scoones, I., Eds.; Routledge: Abingdon, UK, 2003; pp. 131-142.

94. Mahmoud, H.A. Conflicts and Pastoral Livelihoods in the Kenya-Ethiopia-Somalia Borderlands. In Fighting for Inclusion: Conflicts among Pastoralists in Eastern Africa and the Horn; Goldsmith, P., Ed.; Development Management Policy Forum: Nairobi, Kenya, 2009; pp. 53-78.

95. Lake Turkana Wind Power (LTWP). Winds of change. 2018. Available online: https://ltwp.co.ke/ (accessed on 22 October 2018).

96. Hjort, A. Ethnic Transformation, Dependency and Change. The Ilgira Samburu of Northern Kenya. In Change and Development in Nomadic and Pastoral Societies; Galaty, J.G., Salzman, P.C., Eds.; E.J. Brill: Leiden, The Netherlands, 1981; pp. 50-67.

97. Foucault, M. Afterword: The Subject and Power. In Michel Foucault: Beyond Structuralism and Hermeneutics; Dreyfus, H.L., Rabinow, P., Eds.; University of Chigano Press: Chicago, IL, USA, 1983; pp. 208-227.

98. Schoneveld, G.; German, L.; Nutakor, E. Land-Based Investments for Rural Development? A Grounded Analysis of the Local Impacts of Biofuel Feedstock Plantations in Ghana. Ecol. Soc. 2011, 16, 10. [CrossRef]

99. Scoones, I.; Graham, O. New Directions for Pastoral Development in Africa. Dev. Pract. 1994, 4, $188-198$. [CrossRef]

100. White, B.; Borras, S.M., Jr.; Hall, R.; Scoones, I.; Wolford, W. The New Enclosures: Critical Perspectives on Corporate Land Deals. J. Peasant Stud. 2012, 39, 619-647. [CrossRef] 
101. Wily, L.A. The Global Land Grab: The New Enclosures. In The Wealth of Commons: A Common World beyond Market E State; Bollier, D., Helfrich, S., Eds.; Levellers Press: Florence, Italy; Amherst, MA, USA, 2013.

102. Borras, S.J.; Franco, J. Global Land Grabbing and Trajectories of Agrarian Change: A Preliminary Analysis. J. Agrar. Chang. 2012, 12, 34-59. [CrossRef]

103. Lavers, T. Patterns of Agrarian Transformation in Ethiopia: State-Mediated Commercialisation and the 'Land Grab'. J. Peasant Stud. 2012, 39, 795-822. [CrossRef]

104. Kamski, B. The Kuraz Sugar Development Project (KSDP) in Ethiopia: Between 'Sweet Visions' and Mounting Challenges. J. East. Afr. Stud. 2016, 10, 568-580. [CrossRef]

105. Turton, D. Wilderness, Wasteland or Home? Three Ways of Imagining the Lower Omo Valley. J. East. Afr. Stud. 2011, 5, 158-176. [CrossRef]

106. Amanor, K.S. Global Resource Grabs, Agribusiness Concentration and the Smallholder: Two West African Case Studies. J. Peasant Stud. 2012, 39, 731-749. [CrossRef]

107. Wily, A. Looking Back to See Forward: The Legal Niceties of Land Theft in Land Rushes. J. Peasant Stud. 2012, 39, 751-775. [CrossRef]

108. Okoth-Ogendo, H.W.O. The Tragic African Commons: A Century of Expropriation, Suppression and Subversion; University of Nairobi: Nairobi, Kenya, 2003.

109. Fairhead, J.; Leach, M.; Scoones, I. Green Grabbing: A New Appropriation of Nature? J. Peasant Stud. 2012, 39, 237-261. [CrossRef]

110. Brock, A.; Dunlap, A. Normalising Corporate Counterinsurgency: Engineering Consent, Managing Resistance and Greening Destruction around the Hambach Coal Mine and Beyond. Political Geogr. 2018, 62, 33-47. [CrossRef]

111. Bracco, S.; Antonelli, M.; Turvani, M.E. Foreign Investment in Land and Corporate Social Responsibility: An Investigation for Africa; African Centre for Technology Studies (ACTS): Nairobi, Kenya, 2015.

112. Agrawal, A. Sustainable Governance of Common-Pool Resources: Context, Methods, and Politics. Annu. Rev. Anthropol. 2003, 32, 243-262. [CrossRef]

113. Borras, S.J.; Franco, J. From Threat to Opportunity-Problems with the Idea of a Code of Conduct for Land-Grabbing. Yale Hum. Rts. Dev. J. 2010, 13, 507.

114. Burke, M.J.; Stephens, J.C. Political Power and Renewable Energy Futures: A Critical Review. Energy Res. Soc. Sci. 2018, 35, 78-93. [CrossRef]

115. Galaty, J.G. Land Grabbing in the Eastern African Rangelands. In Pastoralism and Development in Africa: Dynamic Change at the Margins; Routledge: Abingdon, UK, 2013; pp. 143-153.

116. Tache, B. Rangeland Enclosures in Southern Oromia, Ethiopia. In Pastoralism and Development in Africa: Dynamic Change at the Margins; Routledge: Abingdon, UK, 2013; p. 37.

117. Oba, G. The Sustainability of Pastoral Production in Africa. In Pastoralism and Development in Africa: Dynamic Change at the Margins; Catley, A., Lind, J., Scoones, I., Eds.; Routledge: Abingdon, UK, 2013; pp. 29-36. 